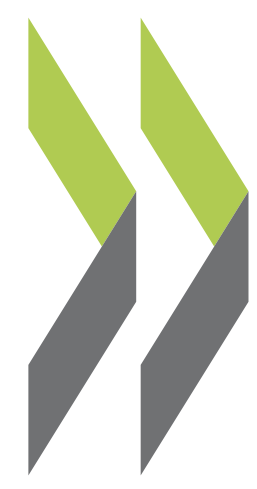

OECD Economics Department Working Papers No. 1249

Economic resilience: A new set of vulnerability indicators for OECD countries

\section{Oliver Röhn,}

Aida Caldera Sánchez, Mikkel Hermansen, Morten Rasmussen 
Organisation de Coopération et de Développement Économiques

Organisation for Economic Co-operation and Development

22-Jul-2015

ECONOMICS DEPARTMENT

English - Or. English

\section{ECONOMIC RESILIENCE: A NEW SET OF VULNERABILITY INDICATORS FOR OECD} COUNTRIES

ECONOMICS DEPARTMENT WORKING PAPERS No. 1249

By Oliver Röhn, Aida Caldera Sánchez, Mikkel Hermansen and Morten Rasmussen

OECD Working Papers should not be reported as representing the official views of the OECD or of its member countries. The opinions expressed and arguments employed are those of the author(s).

Authorised for publication by Christian Kastrop, Director, Policy Studies Branch, Economics Department.

All Economics Department Working Papers are available at www.oecd.org/eco/workingpapers

JT03380361

Complete document available on OLIS in its original format

This document and any map included herein are without prejudice to the status of or sovereignty over any territory, to the delimitation of international frontiers and boundaries and to the name of any territory, city or area. 
OECD Working Papers should not be reported as representing the official views of the OECD or of its member countries. The opinions expressed and arguments employed are those of the author(s).

Working Papers describe preliminary results or research in progress by the author(s) and are published to stimulate discussion on a broad range of issues on which the OECD works.

Comments on Working Papers are welcomed, and may be sent to the Economics Department, OECD, 2 rue André-Pascal, 75775 Paris Cedex 16, France, or by e-mail to eco.contact@oecd.org.

All Economics Department Working Papers are available at www.oecd.org/eco/workingpapers.

The statistical data for Israel are supplied by and under the responsibility of the relevant Israeli authorities. The use of such data by the OECD is without prejudice to the status of the Golan Heights, East Jerusalem and Israeli settlements in the West Bank under the terms of international law.

\section{(C) OECD (2015)}

You can copy, download or print OECD content for your own use, and you can include excerpts from OECD publications, databases and multimedia products in your own documents, presentations, blogs, websites and teaching materials, provided that suitable acknowledgment of OECD as source and copyright owner is given. All requests for commercial use and translation rights should be submitted to rights@oecd.org 


\section{Abstract/Résumé \\ Economic Resilience: A New Set of Vulnerability Indicators for OECD Countries}

The high costs of crises underscore the need to strengthen the resilience of economies, notably by assessing early on potential vulnerabilities that can lead to such costly events. This paper first discusses the source and nature of potential vulnerabilities in OECD countries that can lead to costly economic crises. Based on the most recent evidence from the early warning literature and lessons learned from the global financial crisis, it then proposes a new dataset of more than 70 vulnerability indicators that could be monitored to assess country risks in OECD economies. The indicators are grouped into five domestic areas: i) financial sector imbalances, ii) non-financial sector imbalances, iii) asset market imbalances, iv) public sector imbalances and v) external sector imbalances. An additional international "spillovers, contagion and global risks" category aims at capturing vulnerabilities that could transmit from one country to another through financial, trade or confidence channels. Evidence in a companion paper (Hermansen and Röhn, 2015) shows that the majority of the proposed indicators for which sufficiently long time series exists is helpful in predicting severe recessions and crises in the 34 OECD economies and Latvia between 1970 and 2014.

JEL classification codes: E44; E51; F37; F47

Keywords: Resilience, early warning indicators, vulnerabilities, imbalances, crises, recessions

$* * * * * * *$

\section{Résilience économique: Un nouvel ensemble d'indicateurs de vulnérabilité pour les pays OCDE}

Les coûts élevés des crises soulignent la nécessité de renforcer la résilience des économies, notamment en évaluant à temps les vulnérabilités potentielles qui peuvent causer de tels événements onéreux. Cette étude traite tout d'abord de l'origine et de la nature des vulnérabilités potentielles dans les pays de l'OCDE qui peuvent conduire à des crises économiques coûteuses. Sur la base des résultats documentés dans la littérature récente et des leçons tirées de la crise financière mondiale, l'étude propose ensuite un nouvel ensemble de données de plus de 70 indicateurs de vulnérabilité qui pourraient permettre d'évaluer les risques pays des économies de l'OCDE. Les indicateurs sont regroupés en cinq domaines domestique: i) les déséquilibres du secteur financier, ii) les déséquilibres du secteur non-financier, iii) les déséquilibres du marché des actifs, iv) les déséquilibres du secteur public et v) les déséquilibres du secteur externe. Une catégorie supplémentaire «retombées, contagion et risques globales » vise à capter les vulnérabilités qui pourraient se transmettre d'un pays à un autre par le canal de la finance, du commerce ou de la confiance. Les résultats présentés dans un document connexe (Hermansen et Röhn, 2015) montrent que la majorité des indicateurs proposés ici pour lesquels il existe des séries temporelles suffisamment longues sont utiles pour prévoir les récessions graves et les crises dans les 34 pays de l'OCDE et la Lettonie entre 1970 et 2014.

Mots clefs: Résilience, indicateurs d'alerte rapide, vulnérabilités, déséquilibres, crises, récessions. 
TABLE OF CONTENTS

ECONOMIC RESILIENCE: A NEW SET OF VULNERABILITY INDICATORS FOR OECD
COUNTRIES...

\section{Tables}

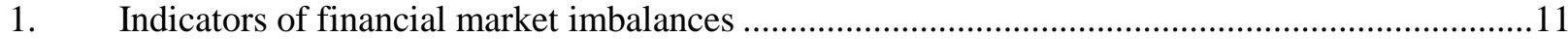

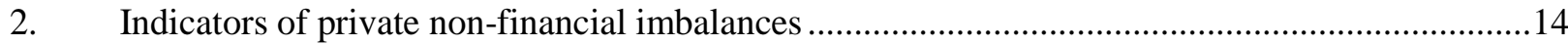

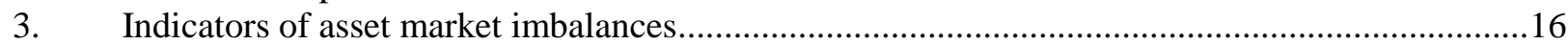

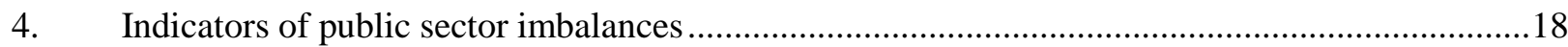

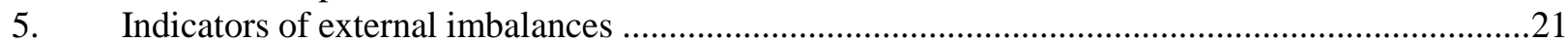

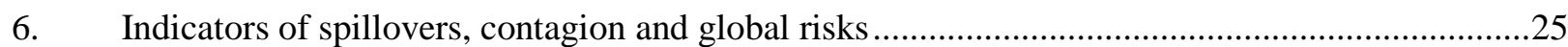

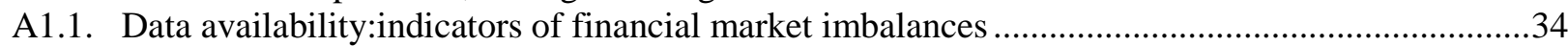

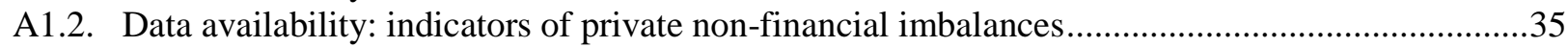

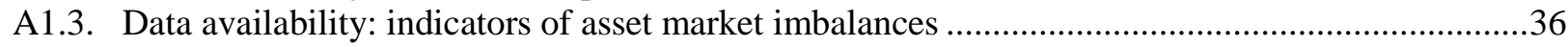

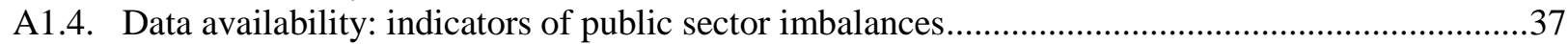

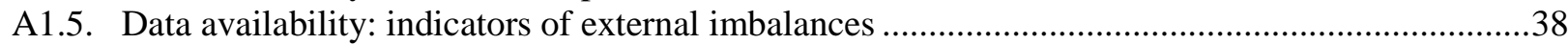

A1.6. Data availability: indicators of spillovers, contagion and global risk ..........................................39

\section{Figures}

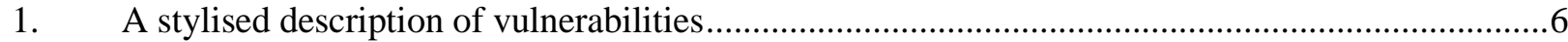

2. Strong private credit growth is a robust predictor of banking crises............................................12

3. Real estate market downturns are often associated with banking crises ....................................15

4. Growing current account deficits are robust indicators of crises .................................................19 
ECO/WKP(2015)67

\title{
ECONOMIC RESILIENCE: A NEW SET OF VULNERABILITY INDICATORS FOR OECD COUNTRIES
}

\author{
By \\ Oliver Röhn, Aida Caldera Sánchez, Mikkel Hermansen and Morten Rasmussen ${ }^{1}$
}

\section{Introduction}

1. The global financial crisis and the high associated economic costs have revived the academic and policy interest in early warning indicators of crises (e.g. Rose and Spiegel, 2011; Frankel and Saravelos, 2012, Alessi and Detken, 2011; Lo Duca, and Peltonen, 2013 among many others). The literature has focused on identifying vulnerabilities that render countries more likely to suffer from costly economic crises, including currency, banking, and sovereign debt crises rather than attempting to predict the exact timing of crises and the triggers that lead to a crisis.

2. This paper discusses the source and nature of potential vulnerabilities that can lead to costly crises in OECD countries, based on the most recent evidence from the early warning literature on currency, banking and sovereign debt crises and lessons learned from the global financial crisis. Drawing lessons from the literature review it then proposes a new dataset of more than 70 indicators that can be monitored to detect vulnerabilities early on and assess country risks of suffering a crisis. ${ }^{2}$ The new dataset provides thus a new tool and complements other OECD tools to monitor country-specific risks.

3. The dataset covers a large set of countries including, to the extent possible, the 34 OECD economies, the BRIICS (Brazil, Russian Federation, India, Indonesia, China and South Africa), Colombia and Latvia. The indicators are grouped into five domestic areas: i) financial sector imbalances, ii) nonfinancial sector imbalances, iii) asset market imbalances, iv) public sector imbalances and v) external sector imbalances. An additional "international spillovers, contagion and global risks" category aims at capturing spillover effects of vulnerabilities arising in one country that could transmit to another country through financial, trade or confidence channels. Figure 1 gives a stylised description of the vulnerabilities covered and illustrates some of the channels through which vulnerabilities build up.

4. Imbalances in each category should not be seen in isolation. Indeed, as discussed in the paper, in the boom phase of the business cycle many of the imbalances interact and can reinforce each other. In the bust phase, the unwinding of one imbalance can trigger the unwinding of others. The simultaneous unwinding of several imbalances will often exacerbate the downturn and deepen the crisis. Conversely, if policymakers tackle one imbalance, they are also likely to reduce vulnerabilities in other sectors.

1. Aida Caldera Sánchez, Mikkel Hermansen and Oliver Roehn are members of the Economics Department of the OECD, while Morten Rasmussen works for Danmarks Nationalbank. The authors are grateful to Alain de Serres, Catherine L Mann, Jean-Luc Schneider and Christian Kastrop for helpful comments and Caroline Abettan for technical and editorial assistance.

2. The terms vulnerabilities and imbalances will be used interchangeably in the following. 
Figure 1. A stylised description of vulnerabilities

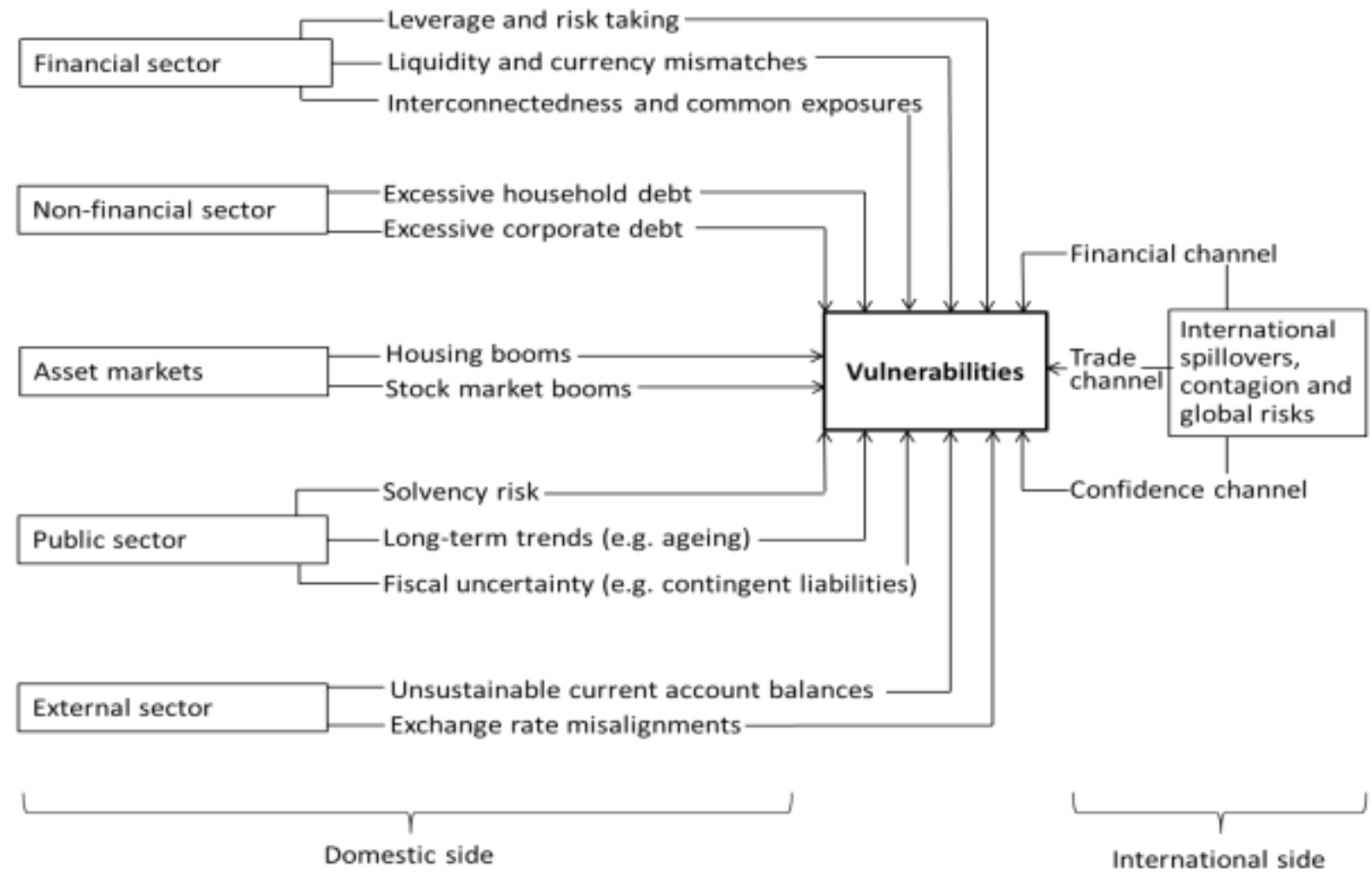

5. The paper extends recent work by the OECD to detect and monitor vulnerabilities. For example, Furceri et al. (2011) and Ahrend and Goujard (2012) investigate how the size and composition of capital inflows affects a country's risk of suffering banking and currency crises or sudden stops. The OECD has also started to systematically monitor and publish indicators of potential macroeconomic and financial vulnerabilities in the Economic Outlook (EO) since the end of 2013 and more recently as part of country Economic Surveys. In this paper the list of vulnerability indicators is substantially extended based on a thorough review of the literature.

6. This paper is part of a stream of work to develop a framework to assess the economic resilience of OECD member countries. In a companion paper, Hermansen and Röhn (2015) provide empirical evidence on the usefulness of the set of vulnerability indicators proposed in this paper to correctly signal severe recessions while avoiding false alarms. They find that the majority of indicators for which sufficiently long time series exists would have helped to predict severe recessions, as well as crises (banking, currency and sovereign debt crises) in the 34 OECD economies and Latvia between 1970 and 2014. Another companion paper (Caldera Sánchez et al., 2015) provides a literature overview of work carried out primarily within, but also outside the OECD, on the impact of macroeconomic, financial market and a range of structural policies on vulnerabilities.

7. The next sections of the paper provide in-depths literature reviews of the type of imbalances that can lead to costly economic events: financial sector imbalances (Section 2), non-financial sector imbalances (Section 3), asset market imbalances (Section 4), public sector imbalances (Section 5), external sector imbalances (Section 6) and spillovers, contagion and global risks (Section 7). At the end of each section a table presents the list of proposed vulnerability indicators, as well as where the data has been 
sourced from. Tables A1.1 to A1.6 in the Appendix 1 provide more details on the country and time coverage for each indicator.

\section{Financial sector imbalances}

8. Theoretically, the link between financial markets and output volatility is ambiguous. Deep and well-functioning financial markets can make economic agents less vulnerable to idiosyncratic shocks by reducing borrowing constraints enabling them to smooth consumption and investment. More developed financial markets may also strengthen monetary policy transmission and hence make monetary policy more effective in countering shocks. By reducing capital adjustment costs, deeper financial markets may also speed up capital reallocation and reduce the persistence to shocks.

9. At the same time, however, financial markets can amplify output volatility through the so-called financial accelerator mechanism. Because of asymmetric information between lenders and borrowers, lenders care about the balance sheet of borrowers, in particular the net worth. In an upturn, the net worth of investors and consumers usually increases, which lowers agency costs (Bernanke and Gertler, 1989) because the borrower has more "skin in the game", and increases the value of collateral (Kiyotaki and Moore, 1997). Both effects will increase the supply of credit, boosting investment and consumption and fuelling the upturn. Asset prices will rise further improving borrowers' balance sheets and consequently further reducing borrowing constraints. In a downturn, this process is reversed, deepening the effect of a negative shock.

10. Overall, the empirical literature suggests that deeper financial markets reduce consumption, investment and output volatility in quiet times (e.g. Blanchard and Simon, 2001; Denizer et al., 2002; Cecchetti et al., 2006; Dynan et al., 2006; Cespedes and Velasco, 2012; Aghion et al., 2010), including previous OECD work (De Serres and Drew, 2004; Duval, Elmeskov and Vogel, 2007). ${ }^{3}$ These empirical findings are, however, conditional on the premise that shocks do not originate in the financial sector and that financial intermediation remains functional in the face of a shock.

11. The financial sector, however, is frequently the epicentre of macroeconomic crises (e.g. Reinhart and Rogoff, 2008; Schularik and Taylor, 2012), as the global financial crisis has forcefully shown. If the financial sector becomes impaired, households and firms lose their ability to smooth shocks and monetary policy is rendered less effective. Through financial accelerator mechanisms, credit shocks can be amplified and transmitted to the wider economy and economic costs of crises involving the financial sector are frequently large. Even a shock to relatively small sub-market of the financial sector, such as defaults in the subprime mortgage market, can become systemic because of amplifying spirals within the financial sector. These amplifying spirals are related to the build-up of several vulnerabilities in the financial sector, including most importantly excessive leverage, maturity mismatches, interconnectedness and common exposures.

\section{Leverage and risk taking}

12. Excessive leverage (assets to equity capital) and risk taking is a recurrent characteristic of the financial sector. A combination of factors explains why financial intermediaries may fail to build-up sufficient (equity capital) risk cushions in boom times. These factors include: i) moral hazard due to explicit or implicit state guarantees and "too-big-to-fail" problems; ii) flawed internal (and rating agency)

3. Easterly et al. (2000) identify a non-linear relationship between financial system development and macroeconomic volatility suggesting limits in the ability to smooth consumption, investment and output, as risks mount with the size of the financial sector. 
risk models that underprice risk in boom times (e.g. Brunnermeier, 2009); iii) competitive pressures forcing financial intermediaries to increase return on equity (e.g. Hanson et al., 2011); iv) biases in the tax system favouring debt over equity financing; and v) insufficient regulation following financial market liberalizations (Cabral, 2013) leading inter alia to regulatory arbitrage for example through the setup of special purpose vehicles off banks' balance sheet.

13. High leverage in the financial sector amplifies the adverse effects of a shock. Two mechanisms are at play: First, financial intermediaries with high leverage, which are hit by a shock depleting their equity, are more likely to reduce assets. While financial intermediaries could in principle let their leverage ratio increase following a shock to equity, this may be unfeasible in practice due to regulatory or internal risk management requirements or because a further increase in the leverage ratio may raise doubts about solvency, hampering access to funding. Furthermore, restoring the initial leverage ratio by raising new equity may be difficult under depressed market conditions or because of the so-called debt overhang problem. ${ }^{4}$ Hence, shedding assets may be the only viable option. Second, the higher the initial leverage ratio, the larger the need to shrink the asset side of the balance sheet to restore the initial leverage ratio. ${ }^{5}$ The implications of these two mechanisms can be dire if the financial sector is hit by a common shock. If several highly-leveraged institutions are forced to reduce assets at the same time, credit crunches may ensue and intermediaries may have to fire sale assets at substantially depressed prices. Depressed asset prices may set in motion an amplifying spiral, forcing financial intermediaries to further deleverage and this may spill over to other financial firms, who hold the same or similar assets. The tightening of credit conditions and falling asset prices depresses consumption, investment and employment, further deteriorating financial intermediaries' balance sheets.

14. Indicators of leverage have been shown to help predict banking crisis (Barrell et al., 2010; Kato et al., 2010; Behn et al., 2013). These measures could be complemented with capital ratios, which take into account the risk profile of assets, although these measures have been shown to be less effective in curbing banks' credit risk (Blundell-Wignall and Roulet, 2014). However, these indicators alone are not likely to give an accurate picture of leverage and risk taking in the financial sector, because data on leverage and capital ratios is usually only available for traditional deposit taking banks. Yet, leverage increased particularly strongly in the shadow banking system in the run-up to the global financial crisis. Hence, indicators measuring the size of the shadow banking system would be useful complements. Moreover, periods of high banking profitability are often accompanied by higher risk taking, and higher banking profitability (measured in terms of return on assets or return on equity) has been shown to increase the probability of banking crisis (Behn et al., 2013). In addition, lending standards could also be useful measures of risk taking.

15. Finally, financial institutions considered as "too-big-to-fail" are particularly prone to moral hazard and excessive risk taking. A set of indicators has been developed to identify global systemically important financial institutions (G-SIFI) capturing their size, interconnectedness, substitutability, crossjurisdictional activity and complexity (BIS, 2013) and the Financial Stability Board publishes regularly a

4. The "debt overhang" problem arises once a bank is in serious trouble and its debt is impaired in value. In this case the bank is reluctant to raise new equity even to fund investments that have a positive net present value, because much of the value that is created is siphoned off by the more senior creditors. Given the debt overhang problem, banks that act in the interests of their shareholders will tend to fix their damaged capital ratios by shrinking assets rather than by raising new capital, even when the latter is more desirable from a social perspective (see Myers, 1977).

5. For example, if asset prices drop by USD 20 billion, a bank with leverage of 10 will have to shed asset worth of USD 200 billion to maintain the initial leverage ratio, whereas a bank with initial leverage of 2 will only need to shed assets worth USD 40 billion. 
list of G-SIFIs (e.g. FSB, 2014). An internationally harmonised definition for domestic systemically important financial institutions (D-SIFI) does not exist (yet), despite recent progress. ${ }^{6}$ Based on such a harmonised definition, vulnerability indicators could be constructed for example as the share of assets of D-SIFIs in GDP. However, such a measure would fail to take into account that not all D-SIFIs may pose a threat to financial stability, for example because they are appropriately regulated.

\section{Maturity and currency mismatches}

16. Maturity mismatches on financial intermediaries balance sheets lead to liquidity risk and create further vulnerabilities. While maturity transformation, i.e. investing in long-term assets (e.g. loans) funded by short-term liabilities (e.g. deposits) is the core business of financial intermediaries, this maturity mismatch can become excessive. Deposits generally constitute a relatively stable source of funding even in times of crises despite their short-term nature thanks to deposit insurance. However, the excesses in credit growth leading up to the global financial crisis were largely funded through short-term borrowing in wholesale markets. In these markets, the borrower usually has to secure loans through collateral. If the value of the collateral falls, creditors demand additional collateral through margin calls. Alternatively, if the creditor loses trust in the value of the collateral or the counterparty, the creditor may demand higher margins or haircuts or may refuse to roll-over loans altogether. In both cases, funding liquidity dries up. If the borrower does not hold enough liquid assets (e.g. cash) to compensate the shortfall in funding, the borrower may be forced to sell illiquid assets. If several financial intermediaries are hit by a shock at the same time, this can set in motion the same asset fire sale spirals as described above. In the worst case, runs on wholesale markets may occur, as experienced during the global financial crisis. The combination of asset fire sales with mark-to-market accounting, can turn liquidity problems of the financial sector into solvency problems.

17. Some empirical evidence suggests that liquidity ratios (e.g. liquid assets to total assets) can help predict banking crisis (Barrell et al., 2010). In addition, strong growth in the loan-to-deposit ratio can signal that financial institutions increasingly move away from stable credit funding through deposits to more risky sources of funding such as through wholesale markets. A high dependence on deposits from abroad may also signal liquidity risk, since these deposits may be more prone to swings in investor confidence than domestic deposits. Exchange rate risk may further aggravate liquidity risk, if domestic lending of financial institutions is increasingly funded from abroad and denominated in foreign currency. This foreign currency mismatch risk can be proxied by the net open foreign currency position of the financial sector. ${ }^{7}$

\section{Interconnectedness and common exposures}

18. The high degree of interconnectedness of banks and their common exposures also raise vulnerabilities related to financial contagion and spillovers. Financial interconnectedness refers to direct and indirect linkages among financial institutions. A common linkage stems from contractual obligations (such as ownership, loans, and derivatives) between two institutions. Banks that participate in the interbank market, for instance, become interconnected as they become exposed to one another through lending and borrowing operations. Many financial firms are also connected though over-the-counter products (e.g.

6. The Basel Committee on Banking Supervision (BCBS) published a principles-based minimum framework for domestic systemically important banks (D-SIBs) that is compatible with the G-SIFI framework (BIS, 2012). Several national regulators have since issued guidelines to define domestic systemically important banks (e.g. EBA, 2014).

7. The gross open foreign currency position would allow investigating maturity mismatches between loans (or other assets) to and from abroad. However, data on gross positions is usually not available. 
credit default swaps). These products can lead to very opaque networks of exposures in the absence of clearing houses, aggravating counterparty risk and confidence contagion.

19. The structure of interconnectedness of the financial sector (or the so-called "financial network") determines how an initial shock is transmitted to the rest of the financial system. Network theory shows that many financial networks exhibit a so-called tipping-point property: below a critical level of interconnectedness, initial defaults are contained irrespective of the network structure. Above this threshold, however, initial defaults can turn systemic, leading to the collapse of the entire financial system (IMF, 2014). On the other hand, Acemoglu et al. (2015) show that the size of the shock matters. If the shock is sufficiently small dense networks can enhance financial stability, because a more diversified pattern of interbank liabilities guarantees that the burden of any potential losses is shared among more counterparties. However, in the presence of large shocks, highly diversified lending patterns facilitate financial contagion and create a more fragile system, whereas "weakly connected" financial networks - in which different subsets of banks have minimal claims on one another-are significantly less fragile.

20. Financial interconnectedness can also lead to moral hazard and excessive risk taking for firms considered "too interconnected to fail". But even if financial institutions are not linked through financial obligations, contagion can arise from common exposure when financial firms invest in the same type of assets (e.g. mortgage backed securities or sovereign bonds).

21. Measuring the interconnectedness and common exposures of the financial system with simple indicators is difficult. This would require bank level data on bilateral exposures, which is scarce and often partial or of limited quality (Arregui et al., 2013). However, aggregate data can give some useful hints. For example, the total amount of intra-financial sector assets and liabilities could proxy for interconnectedness. The share of loans to a particular sector (for example mortgage loans) or the share of particular asset classes (for example sovereign bonds) in total assets could signal common exposures in the financial sector.

\section{Spillovers of financial vulnerabilities to other sectors}

22. Vulnerabilities in the financial sector can spill over to other sectors. Strong credit growth can increase debt levels in the non-financial sector potentially increasing non-financial sector vulnerabilities (see next section). If the financial sector becomes impaired, credit crunches may force the non-financial sector to deleverage depressing investment and consumption. Financial sector vulnerabilities also interact with the external sector. The financial sector may fund part of the expansion of its assets from abroad. The ensuing capital inflows lead to a deterioration of the current account and increase the risks of capital flow reversals and sudden stops. Finally, the euro area crisis is a good example of the close linkages between the financial and the public sector (OECD 2012a, b). Uncertainty about the health of the banking sector and the eventual bailing out of banks by governments negatively affected confidence in public solvency. The ensuing higher risk premia on government bonds fed back into the banking sector, which usually holds sizeable amounts of government bonds. As the case of Ireland has shown, recapitalisation costs and implicit guarantees of bank debt (Schich and Lindh, 2012) can indeed threaten public solvency. Sutherland et al. (2012) provide some empirical evidence that financial sector debt tends to migrate to the public sector in times of crisis. 
Table 1. Indicators of financial sector imbalances

\begin{tabular}{|c|c|c|c|}
\hline Indicator & Description & $\begin{array}{c}\text { Data } \\
\text { Source }\end{array}$ & Available? \\
\hline \multicolumn{4}{|l|}{ Leverage and risk taking } \\
\hline Financial sector gross financial liabilities * & $\begin{array}{l}\text { Defined as liabilities less financial derivatives and } \\
\text { shares and other equity, in per cent of GDP. } \\
\text { Based on consolidated data for most countries. }\end{array}$ & OECD & Yes \\
\hline Leverage ratio * & $\begin{array}{l}\text { Defined as regulatory (tier 1) capital to total } \\
\text { (unweighted) assets. }\end{array}$ & IMF & Yes \\
\hline Capital ratio & $\begin{array}{l}\text { Defined as regulatory (tier1) capital to risk- } \\
\text { weighted assets }\end{array}$ & IMF & Yes \\
\hline Shadow Banking & $\begin{array}{l}\text { Other financial sector assets to GDP or to total } \\
\text { financial sector assets }\end{array}$ & IMF & Yes \\
\hline Return on Assets & $\begin{array}{l}\text { Net income before extraordinary items and taxes } \\
\text { to total assets. }\end{array}$ & IMF & Yes \\
\hline Return on Equity & $\begin{array}{l}\text { Net income before extraordinary items and taxes } \\
\text { to total capital and reserves. }\end{array}$ & IMF & Yes \\
\hline Lending standards & $\begin{array}{l}\text { Change in credit standards (tightened or eased) } \\
\text { for enterprises the last three months. }\end{array}$ & ECB & Yes \\
\hline Too big to fail & & & No \\
\hline \multicolumn{4}{|l|}{ Liquidity and currency mismatches } \\
\hline Liquidity ratio & $\begin{array}{l}\text { Liquid assets to total assets or to short term } \\
\text { liabilities }\end{array}$ & IMF & Yes \\
\hline Loan-to-deposit ratio & $\begin{array}{l}\text { Total (non-interbank) gross loans to customer } \\
\text { deposits. }\end{array}$ & IMF & Yes \\
\hline Deposits from abroad & $\begin{array}{l}\text { Total liabilities to non-residents, currency and } \\
\text { deposits, in per cent of total liabilities. }\end{array}$ & IMF & Yes \\
\hline Foreign currency mismatch & Net open position in foreign exchange to capital. & IMF & Yes \\
\hline \multicolumn{4}{|l|}{$\begin{array}{l}\text { Interconnectedness and common } \\
\text { exposures }\end{array}$} \\
\hline Interconnectedness & & & No \\
\hline Housing loans & Residential real estate loans to total loans & IMF & Yes \\
\hline Commercial real estate loans & Commercial real estate loans to total loans & IMF & Yes \\
\hline Domestic sovereign bonds & $\begin{array}{l}\text { Domestic government securities owned in per } \\
\text { cent of total assets. }\end{array}$ & IMF & Yes \\
\hline
\end{tabular}

* denotes indicators that are included in the OECD Economic Outlook (Table A1).

\section{Non-financial sector imbalances}

23. This section focuses mainly on vulnerabilities stemming from balance sheets imbalances of the non-financial sector that may result in financial instability. The reason is that the literature on early warning signals of crises has largely focused on these vulnerabilities.

24. An extensive literature documents the economic costs associated with rapid increases in private sector credit. Strong credit growth has been identified as one of the most robust early warning indicators of financial crises (see Figure 2 and e.g. Borio and Lowe, 2002; Borio and Drehmann, 2009; Kaminsky and Reinhart, 1999; Reinhart and Rogoff, 2008; Schularick and Taylor, 2012; Taylor, 2012; Jordà et al., 2010). More credit-intensive economic expansions tend to be followed by deeper recessions and slower recoveries (Jordà et al., 2013; Sutherland and Hoeller, 2012). The severity of the recession will depend on the joint build-up of vulnerabilities in different sectors and in particular whether the bust of the credit boom will result in a full-blown banking crisis. But even if credit booms do not lead to a full-blown banking crisis, recoveries are often muted (Dell'Ariccia et al., 2012). In addition, recent OECD research has found that 
higher credit growth prior to the 2008/09 crises is associated with higher losses of potential output (Ollivaud and Turner, 2015).

\section{Figure 2. Strong private credit growth is a robust predictor of banking crises}

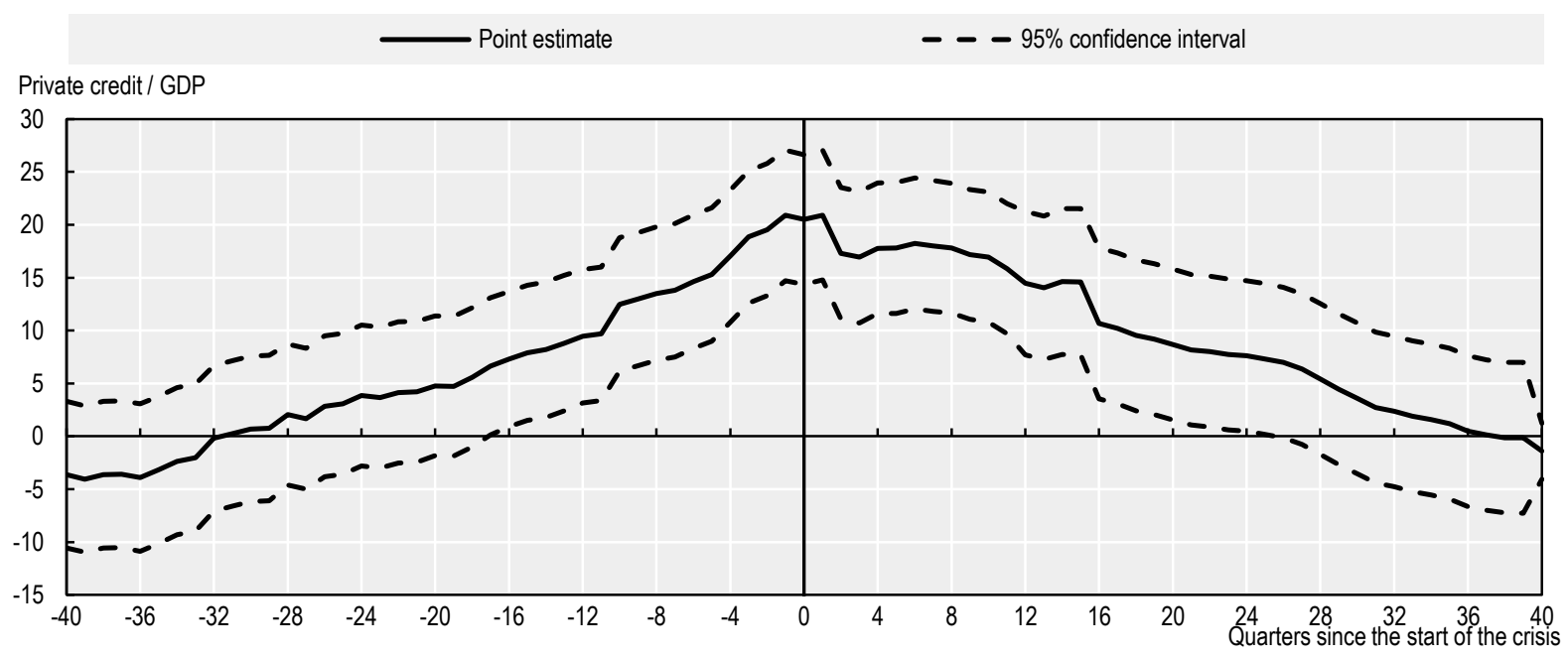

How to read this figure: The solid line shows the percentage point change on average across countries and episodes in private credit in per cent of GDP 10 years before and 10 years after a banking crisis relative to normal times. The point estimate (solid line) and confidence interval (dashed lines) are obtained by a difference-in-difference panel estimation controlling for country and time fixed effects. For more details, see Appendix 2.

25. Private and especially household debt grew rapidly in many OECD countries in the decades prior to the global financial crisis (Sutherland and Hoeller, 2012). This secular increase was mainly triggered by financial deregulation and innovation. In particular, the emergence of mortgage securitisation greatly helped channel large amounts of funds into the mortgage market and facilitated the extension of mortgage credit to lower-income groups (e.g. Ramskogler, 2014). However, especially for the United States, the increase in household debt has also been linked to widening income inequality (e.g. Rajan, 2010). People's subjective wellbeing does not only depend on absolute consumption, this argument suggests, but also on the consumption relative to peers. Growing income inequality may have induced lower-income households to increasingly go into debt to "Keep up with the Joneses" (e.g. Bertrand and Morse, 2013). This explanation is consistent with the empirical finding of a significant co-movement between household debtto-GDP ratios and indicators of income inequality in the decades preceding the global financial crisis and the great depression (Kumhof et al., 2013).

26. High levels of private debt can make the private sector more vulnerable to shocks and intensify and prolong economic downturns. Private debt can contribute to macroeconomic stability as it allows households and enterprises to smooth consumption and investment in the face of temporary income and revenue shocks. However at higher levels of debt, this ability can be hampered. As debt represents a nonstate contingent liability, debt-service payments are independent of the state of the economy. At high levels of debt, a negative income or revenue shock can squeeze cash flows and force households and firms to cut back on consumption and investment. Similarly, at higher levels of debt, asset price shocks (such as declines in house prices) will have larger effects on net wealth. Lower net wealth will translate into lower private spending (e.g. Davis, 2010) and also reduce access to borrowing, forcing households and firms to 
deleverage (see above) ${ }^{8}$ If debt and capital overhangs are sizeable, this deleveraging process may depress economic activity for protracted periods. Recent OECD empirical analysis (Sutherland and Hoeller, 2012) shows that high household and non-financial corporate sector levels of debt relative to trend help predict crises. While the predicted probability of a recession occurring in the following year is around $10 \%$ when household debt is at trend, it rises to over $40 \%$ once debt rises above trend by $10 \%$ of GDP. While the effect is large, such an increase above trend is relatively rare.

27. Balance sheet maturity and currency mismatches tend to aggravate non-financial sector vulnerabilities for both firms and households. For example, high levels of short-term liabilities can expose firms to roll-over or interest rate risks. High levels of household mortgages denominated in foreign currency, as was the case in several OECD countries prior to the 2008-09 crisis (e.g. Poland and Hungary), expose households to exchange rate risks.

28. Vulnerabilities on the balance sheets of non-financial firms and households can spread to the financial sector. This is particularly the case as strong credit growth is often accompanied by a loosening of credit standards to more risky clients (Mendoza and Terrones, 2008). The global financial crisis is a case in point. It started with the defaults of borrowers in the subprime mortgage market. This triggered a liquidity and solvency crisis in the financial sector. The financial sector then amplified vulnerabilities through the ensuing credit crunch, which forced the non-financial sector to deleverage more broadly.

29. Non-financial sector vulnerabilities may also spill over to the public and external sectors. The government can be placed in an unenviable position of having to rescue parts of the non-financial corporate sector. More indirectly, but quantitatively more important, government budgets are affected by cyclical weakness as other sectors deleverage, through automatic budget reactions as well as countercyclical fiscal policy. Finally, credit booms may result in a reallocation of resources away from the tradable to the non-tradable sector (for example from other sectors to residential investment during a housing boom). This may lead to deterioration of the trade and current account balance, as was for instance the case in Spain in the run up to the crisis. In this context, Jordà et al. (2010) note that the correlation between lending booms and current account imbalances has become tighter in recent decades.

8. In principle, as highly indebted borrowers stop spending, less indebted borrowers or lenders could take up the slack. For example, wealthy households could purchase goods at reduced prices and cash-rich firms could invest at improved expected return. But as Eggertson and Krugman (2012) point out, it is the asymmetry between those who are highly indebted and those who are not that leads to a decline in aggregate demand. In particular, debtors have borrowed for good reasons, most of which indicate a high marginal propensity to spend from wealth or from current income or from any other liquid resources they can command. 
Table 2. Indicators of private non-financial imbalances

\begin{tabular}{|c|c|c|c|}
\hline Indicator & Description & $\begin{array}{c}\text { Data } \\
\text { Source }\end{array}$ & Available? \\
\hline Total private credit & $\begin{array}{l}\text { Lending from all sectors (including foreign) } \\
\text { to private non-financial sector in per cent of } \\
\text { GDP. }\end{array}$ & BIS & Yes \\
\hline Private bank credit & $\begin{array}{l}\text { Lending from domestic bank sector to } \\
\text { private non-financial sector in per cent of } \\
\text { GDP. }\end{array}$ & BIS & Yes \\
\hline External debt & $\begin{array}{l}\text { Other sectors (households, non-financial } \\
\text { corp., non-deposit taking financial corp.) } \\
\text { external debt, percentage of GDP. }\end{array}$ & World Bank & Yes \\
\hline \multicolumn{4}{|l|}{ Households } \\
\hline Household credit & $\begin{array}{l}\text { Lending from all sectors (including foreign) } \\
\text { to households in per cent of GDP. }\end{array}$ & $\mathrm{BIS}$ & Yes \\
\hline Household gross financial liabilities * & $\begin{array}{l}\text { Defined as liabilities less financial } \\
\text { derivatives and shares and other equity, in } \\
\text { per cent of net household disposable } \\
\text { income. Based on consolidated data for } \\
\text { most countries. }\end{array}$ & OECD & Yes \\
\hline Debt service costs & $\begin{array}{l}\text { Household debt service and principal to } \\
\text { gross disposable income. }\end{array}$ & IMF & Yes \\
\hline Foreign currency denominated liabilities & $\begin{array}{l}\text { Outstanding amount at the end of the } \\
\text { period; in per cent of GDP. }\end{array}$ & ECB & Yes \\
\hline Short-term (<1 year) & $\begin{array}{l}\text { Short-term loans in per cent of total } \\
\text { household liabilities. }\end{array}$ & OECD & Yes \\
\hline \multicolumn{4}{|l|}{ Non-financial corporations } \\
\hline Corporate credit & $\begin{array}{l}\text { Lending from all sectors (including foreign) } \\
\text { to non-financial corporations in per cent of } \\
\text { GDP. }\end{array}$ & BIS & Yes \\
\hline $\begin{array}{l}\text { Non-financial corporations gross financial } \\
\text { liabilities * }\end{array}$ & $\begin{array}{l}\text { Defined as liabilities less financial } \\
\text { derivatives and shares and other equity, in } \\
\text { per cent of GDP. Based on consolidated } \\
\text { data for most countries. }\end{array}$ & OECD & Yes \\
\hline Foreign currency denominated liabilities & $\begin{array}{l}\text { Outstanding amount at the end of the } \\
\text { period; in per cent of GDP. }\end{array}$ & ECB & Yes \\
\hline Short-term (<1 year) & $\begin{array}{l}\text { Short-term debt securities and loans in per } \\
\text { cent of total corporate liabilities. }\end{array}$ & OECD & Yes \\
\hline
\end{tabular}

${ }^{*}$ denotes indicators that are included in the OECD Economic Outlook (Table A1).

\section{Asset market imbalances}

30. Asset market (equity and real estate) busts are often associated with economic downturns. Especially real estate market crashes have been found to be particularly costly. From a historical perspective, two out of five real estate market downturns have been associated with systemic banking crises in advanced economies (see Figure 3 and e.g. IMF, 2012). What stands out is the duration and extent of the build-up of the housing boom before a correction takes place. This may explain why recessions associated with housing price busts tend to be deeper and longer than other recessions (Claessens et al., 2011) and can have far-reaching consequences, including for macroeconomic and financial stability (Crowe et al., 2013).

31. Asset market imbalances can affect the real economy through wealth and financial accelerator mechanisms. Increases in the market value of assets can encourage additional spending leading to changes 
in aggregate demand through the so-called wealth channel. Wealth effects on consumption are mainly driven by real estate prices, given the typically high share of housing wealth compared to financial wealth in household portfolios. These effects are usually found to be larger in English-speaking countries and are related to mortgage market characteristics, such as the ease of mortgage equity withdrawals (Catte et al., 2004; Davis, 2010).

Figure 3. Real estate market downturns are often associated with banking crises

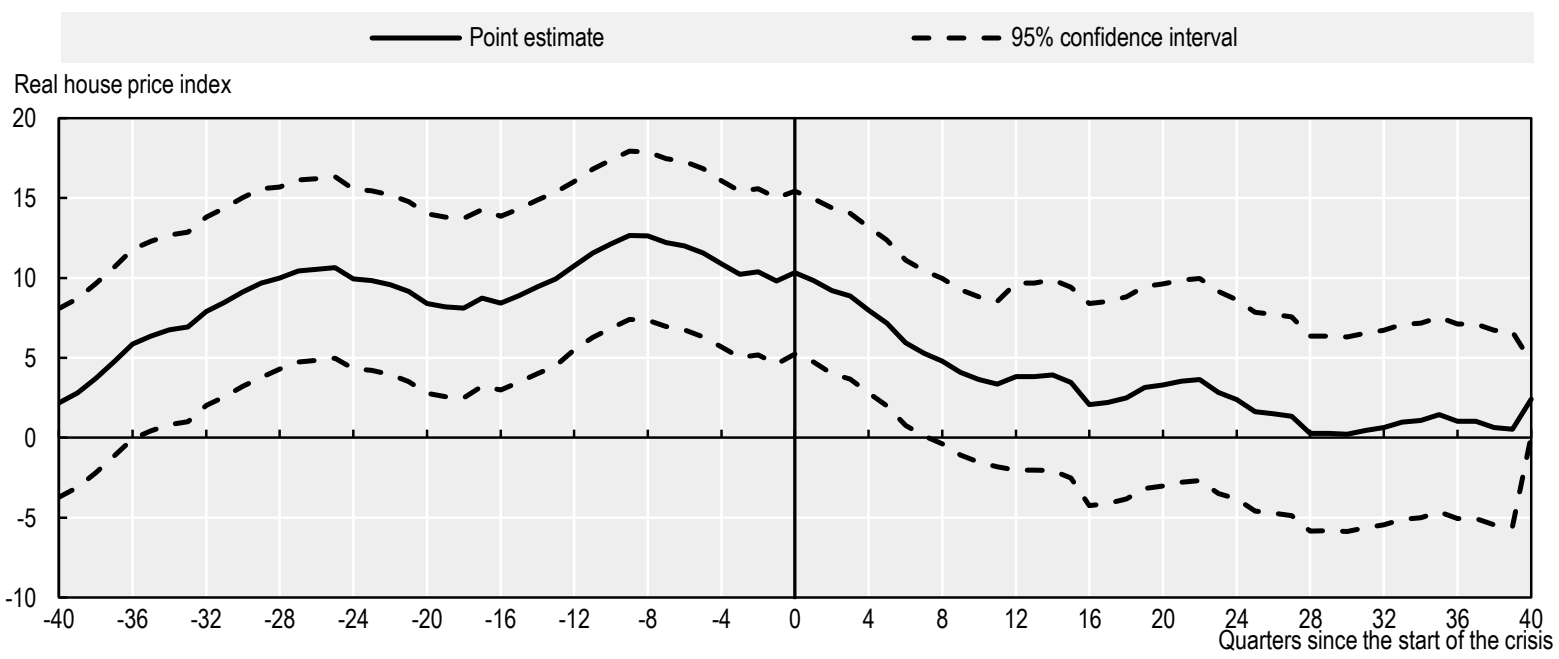

How to read this figure: The solid line shows the percentage point change on average across countries and episodes in real housing prices 10 years before and 10 years after a banking crisis relative to normal times. The point estimate (solid line) and confidence interval (dashed lines) are obtained by a difference-in-difference panel estimation controlling for country and time fixed effects. For more details, see Appendix 2.

32. Higher asset prices facilitate access to credit of households and firms via the financial accelerator mechanism boosting private spending and economic activity. Depending on the amount of leverage buildup during the boom, asset price declines and the associated tightening of available credit can force households and firms to substantially deleverage including through defaults. The distress in household and non-financial firms' balance sheets can quickly spread to financial sector balance sheets resulting in even tighter lending standards and further private sector deleveraging. Apart from their exposure through loans, financial institutions can also be affected through other asset holdings. For example, prior to the global financial crisis, financial firms held substantial amounts of mortgage backed securities, which were partly used as collateral in wholesale market funding operations. Once the value of collateral declined, financial firms found it increasingly difficult to roll-over their short-term funding needs, triggering asset fire sales (see section on financial market imbalances above).

33. Besides interlinkages with private sector balance sheets, house price booms can affect the real economy if they are associated with booms in residential investment. A case in point is the construction boom in some European countries prior to the crisis. Long-term averages for residential investment are normally around 4-6 per cent of GDP in OECD countries (André, 2010). But the share rose to above 10\% of GDP in Ireland and Spain during the height of the construction boom in the 2000s. The impact of housing booms on employment can be even larger as the sector is very labour intensive. For instance, during the latest expansion, construction contributed significantly to employment growth not only in Spain and Ireland but also in Finland, France, Italy, Denmark and the United States (André, 2010). Housing busts can therefore lead to large reallocations of labour between sectors entailing important adjustment costs. The responsiveness of housing supply to changes in prices plays an important role in shaping housing market developments (Andrews et al., 2011). During boom periods, inelastic housing supply reinforces 
house price overvaluation. On the other hand, a high supply elasticity coupled with expectations of future housing price rises may lead to overshooting in construction activity.

34. Developments in asset markets may also spill over to the public sector. Asset price booms can create sizeable windfall revenues for governments (Price and Dang, 2011). This can render fiscal policy pro-cyclical if the extra revenues are not identified as temporary, and instead used to fund additional spending or tax cuts. While further boosting the economy, this also reduces the fiscal space once the asset bubble bursts and the extra revenues vanish.

35. Detecting asset imbalances with a reasonable degree of certainty in real time is challenging. Even sharp changes in asset prices do not need to be associated with bubbles. Instead they can reflect fundamentals leading to increasing demand, such as demographics, higher disposable income, mortgage market (de-)regulation, lower interest rates and tax rates for house prices, and higher profit expectations for stock prices. Fundamentals can be hard to observe or interpret in real-time. However, a number of statistics can point to unsustainable asset price developments. For example, rapid real house and equity price growth and large deviations from trend have been found to be useful in predicting economic crises (e.g. Borio and Drehmann, 2009; Lo Duca and Peltonen, 2013; Babecky et al., 2013; Behn et al., 2013).

36. Large deviations of price-to-income and price-to-rent ratios from their historical norms are generally reversed at some point (e.g. Girouard et al., 2006). If housing prices are increasing faster than average disposable income, fewer people can afford to buy a house lowering housing demand and prices. In the same way if housing prices rise faster than rents there should be a substitution towards renting pushing down prices. This adjustment can be of limited macro consequences if the correction takes place at a stage of small misalignments. In practice, past experience has shown that house price misalignments can often be large and protracted, leading to abrupt and severe corrections. Similarly, for equity markets large deviations of (cyclically-adjusted) price-to-earning ratios from a long-run trend could signal misalignments. Finally, residential investment booms very rarely end in soft landings (Hoeller and Rae, 2007). These can be spotted by monitoring deviations of residential investment as a \% of GDP and the share of employment in construction from long-run trends.

Table 3. Indicators of asset market imbalances

\begin{tabular}{llll}
\hline \multicolumn{1}{c}{ Indicator } & \multicolumn{1}{c}{ Description } & $\begin{array}{c}\text { Data } \\
\text { Source }\end{array}$ & Available? \\
\hline $\begin{array}{l}\text { Housing } \text { markets } \\
\text { Real house prices }{ }^{*}\end{array}$ & Deflated by CPI & OECD & Yes \\
Price-to-disposable income ratio & $\begin{array}{l}\text { Nominal house prices to nominal net } \\
\text { household disposable income per capita }\end{array}$ & OECD & Yes \\
Price-to-rent ratio & Nominal house prices to rent prices. & OECD & Yes \\
Residential investment as \% of GDP & $\begin{array}{l}\text { Gross fixed capital formation, housing, in } \\
\text { per cent of GDP. }\end{array}$ & OECD & Yes \\
Employment in construction & As a percentage of total employment & OECD & Yes \\
Equity markets & & OECD \\
Real stock prices & & Yes \\
Price-to-earnings ratio (cyclically-adjusted) & & Share price index deflated by CPI \\
\hline
\end{tabular}

* denotes indicators that are included in the OECD Economic Outlook (Table A1).

\section{Public sector imbalances}

37. Doubts about the sustainability of public finances can have profound consequences for the economy. When sovereign solvency is perceived at risk, investors demand higher risk premia on government debt, which affects private demand via interest rate and balance sheet channels (Corsetti et al., 2012). The extent to which private demand is affected depends on the monetary policy reaction. For 
example, if policy rates are close to the zero lower bound monetary policy cannot counteract the rise in interest rates. Monetary policy may also be constrained by a fixed exchange rate regime. Similarly, in a currency union monetary policy may not react to increasing interest risk premia in one country because the policy rate is set at the optimal level for the entire union. As the euro area crisis has shown, when markets turn against a country perceived at risk of insolvency, high risk premia may force the country to procyclically tighten the fiscal stance to regain market confidence. ${ }^{9}$

38. At the most basic level, sovereign solvency risk is influenced by the debt level, current and future levels of the primary budget balance and the difference between interest rates on government debt and GDP growth (Baldacci et al., 2011a). Changes to the level or future path of these variables, may result in a reassessment of government solvency risk. Government net debt, i.e. gross debt minus government assets, is the theoretically preferred debt concept to evaluate sustainability issues, because government assets could be sold to reduce debt in times of crisis. However, the liquidity of asset may differ and certain assets may be earmarked for specific purposes and are thus not available to be sold in times of crises. Information on the liquidity structure of assets is generally not available. In addition, valuation and accounting differences across countries and the lack of data on non-financial assets in many countries hampers international comparisons of government assets. Hence, gross debt is frequently used to assess sustainability and solvency risk.

39. Empirically, Babecky et al. (2013) show that a high government gross debt to GDP ratio is a robust predictor of the occurrence and severity of currency, banking and sovereign debt crises in their sample of advanced economies. Baldacci et al. (2011b) find the difference between the government interest rate and GDP growth to be a particularly good predictor of fiscal stress episodes in advanced economies.

40. Vulnerabilities to sovereign solvency can also arise from secular demographic and economic trends. Since solvency depends not only on the current fiscal position but also on expected future primary balances, projections of long-term fiscal challenges could affect solvency risk today. The Report OECD@100: Economic Policies for a Shifting World (OECD, 2014a) and recent OECD work on the vulnerability of social institutions (OECD, 2014b) highlighted that population ageing will put pressure on the sustainability of pay-as-you-go pension systems in many OECD countries, while long-term cost and technology developments are the main drivers of future health-related public spending (see also de la Maisonneuve and Oliveira Martins, 2013). These spending pressures will have profound implications on consolidation needs to obtain sustainable debt levels (OECD, 2014b).

41. For a given fiscal solvency outlook, the government debt composition may influence vulnerabilities. Other things equal, a greater need to access the market in the short term means a higher risk of adverse market reactions when solvency risks are high and/or risk appetite low. A large share of shortterm debt means more exposure to roll-over and interest rate risks in the near term. This is particularly true if current financial market conditions are unfavourable. The gross financing need (the sum of the overall balance and the stock of maturing public debt), the share of short-term debt in total debt and weighted average maturity of outstanding government debt are potential proxies for these risks. The gross financing need has been found to be a good predictor of fiscal stress episodes in advanced economies (Baldacci et al., 2011b). In addition, countries with a large share of the public debt denominated in foreign currency (typically EMEs) are exposed to exchange rate risk. Furthermore, countries with a large share of public debt held by non-residents may be more vulnerable to swings in foreign investor confidence, because they could be perceived as being more likely to address solvency problems by "taxing foreigners" through default rather than through corrective actions.

9. The following discussion and the selection of vulnerability indicators is largely based on Cottarelli (2011) and Baldacci et al. (2011a,b) who developed a fiscal framework to assess fiscal vulnerabilities for the IMF Fiscal Monitor. 
Table 4. Indicators of public sector imbalances

\begin{tabular}{|c|c|c|c|}
\hline Indicator & Description & $\begin{array}{c}\text { Data } \\
\text { Source }\end{array}$ & Available? \\
\hline \multicolumn{4}{|l|}{ Basic fiscal solvency } \\
\hline Primary budget balance & $\begin{array}{l}\text { Cyclically adjusted (or underlying) } \\
\text { government primary budget deficit in per } \\
\text { cent of potential GDP. }\end{array}$ & OECD & Yes \\
\hline General government budget balance * & In per cent of GDP & OECD & Yes \\
\hline General government debt * & Gross government debt in per cent of GDP & OECD & Yes \\
\hline$(r-g) *$ & $\begin{array}{l}\text { Real } 10 \text {-year sovereign bond yield- } \\
\text { potential GDP growth rate differential. }\end{array}$ & OECD & Yes \\
\hline \multicolumn{4}{|l|}{ Long-term fiscal solvency } \\
\hline Future public spending on pensions & $\begin{array}{l}\text { Projections of future public expenditure on } \\
\text { pensions in per cent of GDP. }\end{array}$ & OECD & Yes \\
\hline $\begin{array}{l}\text { Future public spending on health and long- } \\
\text { term care }\end{array}$ & $\begin{array}{l}\text { Projections of future health and long-term } \\
\text { care costs in per cent of GDP. }\end{array}$ & OECD & Yes \\
\hline Projected old-age support ratio & $\begin{array}{l}\text { Projections of number of people in working } \\
\text { age }(20-64) \text { relative to number of people in } \\
\text { retirement age }(65+) \text {. }\end{array}$ & OECD & Yes \\
\hline \multicolumn{4}{|l|}{ Government debt composition } \\
\hline Gross financing needs & $\begin{array}{l}\text { Public budget deficit + short-term debt by } \\
\text { original maturity + long-term debt with } \\
\text { payment due in one year or less, in per } \\
\text { cent of GDP. }\end{array}$ & $\begin{array}{l}\text { OECD, } \\
\text { World Bank }\end{array}$ & Yes \\
\hline Short-term debt & $\begin{array}{l}\text { Short-term gross general government debt } \\
\text { in per cent of gross general government } \\
\text { debt. }\end{array}$ & World Bank & Yes \\
\hline $\begin{array}{l}\text { Weighted average maturity of general } \\
\text { government debt }\end{array}$ & & & No \\
\hline Debt denominated in foreign currency & $\begin{array}{l}\text { In per cent of gross general government } \\
\text { debt. }\end{array}$ & World Bank & Yes \\
\hline Debt held by non-residents & $\begin{array}{l}\text { External gross general government debt in } \\
\text { per cent of gross general government debt. }\end{array}$ & World Bank & Yes \\
\hline Short-term external government debt & $\begin{array}{l}\text { In per cent of gross general government } \\
\text { debt. }\end{array}$ & World Bank & Yes \\
\hline \multicolumn{4}{|l|}{ Fiscal risks or uncertainties } \\
\hline Government contingent liabilities & $\begin{array}{l}\text { Guarantees and liabilities recorded off- } \\
\text { balance sheet of government; in per cent of } \\
\text { GDP. }\end{array}$ & Eurostat & Yes \\
\hline
\end{tabular}

* denotes indicators that are included in the OECD Economic Outlook (Table A1).

42. Vulnerabilities can also arise due to the uncertainty associated with the outlook in public finances (e.g. Kopits, 2014). Contingent liabilities of the government are an important source of such uncertainties. These contingent liabilities can be implicit or explicit. Explicit contingent liabilities have a contractual basis and include for example government guarantees for depositors, exporters, farmers, or investors in infrastructure (under public-private partnership contracts), state-owned enterprises or subnational governments. Implicit contingent liabilities have no contractual basis but are driven by expectations created by past practices or pressure from interest groups. They include for example future liabilities of publicly-funded pensions to all employees or guarantees for private pensions, bailout support for important industries in trouble, and costs related to natural disasters. Finally implicit contingent liabilities arising from the financial sector can have devastating effects on fiscal accounts, as witnessed during the recent crisis. 
43. Public sector imbalances can spill over to other sectors. As alluded to above, government finances and financial sector balance sheets are intimately linked through (implicit and explicit) public guarantees and banks' government bond holdings. Hence, shocks to the public sector solvency risk may quickly transmit to the financial sector. Changes in the government budget balance will alter total saving and thereby its current account, reflecting evidence that Ricardian equivalence only holds partially. Recent estimates suggest that a $1 \%$ of GDP change of the fiscal balance alters the current account balance by up to around $0.5 \%$ of GDP (Chinn and Ito, 2008; OECD, 2011). Finally, as discussed above, asset price related tax revenue surprises can be an important source of bias in the assessment of structural budget balances. If not properly taken into account, these biases can render fiscal policy pro-cyclical, prolonging economic and asset price booms and deepening the busts.

\section{External sector imbalances}

44. External imbalances feature prominently among the potential causes of both the global financial meltdown in 2008/09 (e.g. Bernanke, 2009; King, 2009) and the sovereign debt crisis in the euro area (e.g. Barnes, 2010; Chen et al., 2012). The massive capital inflows from emerging Asia into the US government bond market may have pushed down long-term interest rates and led private investors to invest in riskier assets (e.g. Ramskogler, 2014). In the euro area, current account surplus countries may have financed unsustainable consumption and housing booms in high-deficit countries. Empirical evidence suggests that those countries that ran the highest current account deficits in the run-up to the 2008/09 crisis, subsequently experienced the largest falls in GDP (e.g. Lane and Milesi-Ferretti, 2010). Ollivaud and Turner (2015) find that larger current account deficits are correlated with higher potential output losses after the 2008/09 crisis, suggesting misallocation of resources in the pre-crisis boom. Even abstracting from the most recent crisis, surveys of the literature suggest that current account deficits are among the most robust early warning indicators of financial crises (Figure 4 and Frankel and Saravelos, 2012; Csortos and Szalai, 2014).

Figure 4. Growing current account deficits are robust indicators of crises

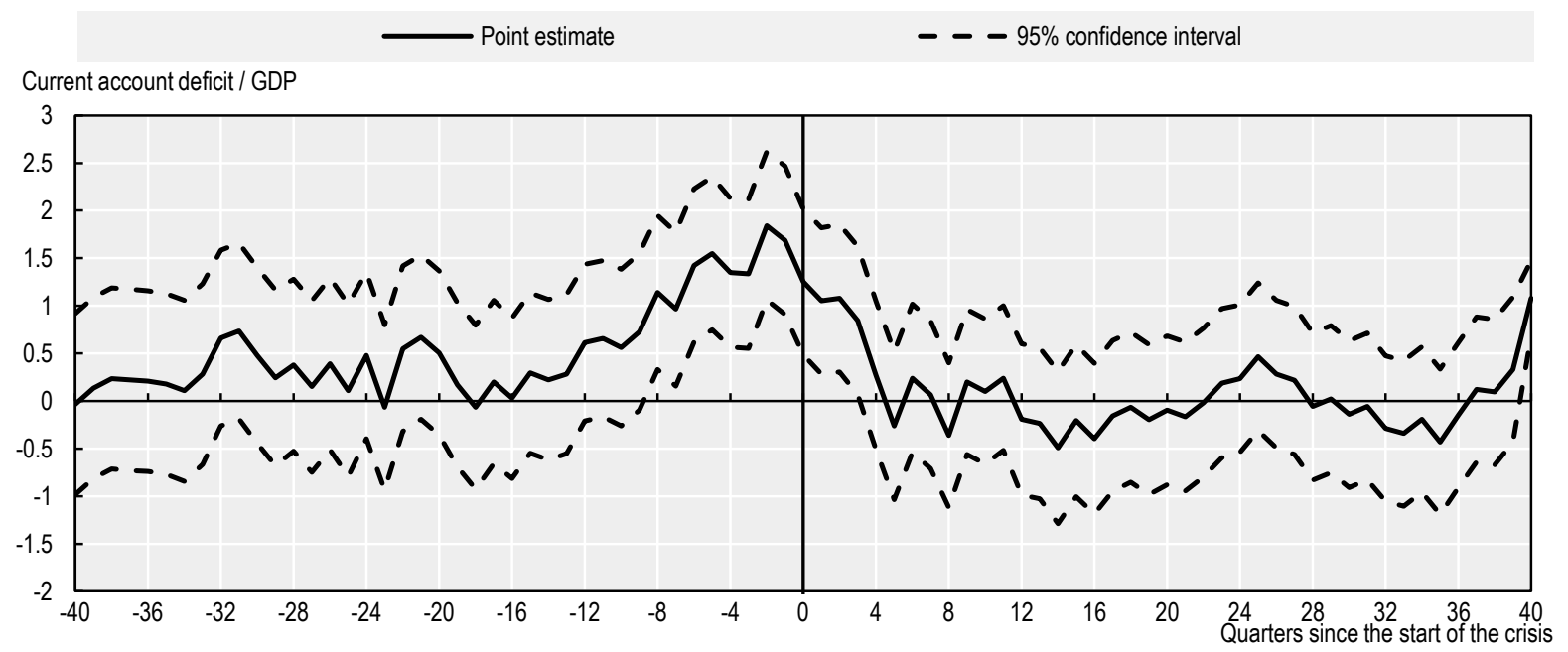

How to read this figure: The solid line shows the percentage point change on average across countries and episodes in the current account deficit in per cent of GDP 10 years before and 10 years after a crisis (banking, sovereign debt or currency) relative to normal times. The point estimate (solid line) and confidence interval (dashed lines) are obtained by a difference-in-difference panel estimation controlling for country and time fixed effects. For more details, see Appendix 2.

45. External imbalances, as commonly measured by the ratio of the current account balance to GDP, provide a summary of the net lending or borrowing of an economy as a whole against the rest of the world. External imbalances can arise for "good" or "bad" reasons (Blanchard and Milesi-Ferretti, 2012), rendering normative assessments of external imbalances challenging. External imbalances can be the result of utility- 
maximising behaviour in the absence of distortions and reflect the optimal allocation of capital across time and space. For example, current account deficits are not uncommon for catching-up economies which, given a certain level of political and macroeconomic stability as well as security of property rights, provide ample investment opportunities and high returns for foreign investors. Current account surpluses may reflect accumulated savings for retirement in an ageing society. However, external imbalances may also be due to policy-induced domestic market distortions. For example, current account deficits may reflect underlying competitiveness problems or may arise due to credit or asset price booms. ${ }^{10}$ Persistent current account surpluses on the other hand can signal a dearth of domestic investment possibilities related to rigid product markets, export-led growth strategies or excessive precautionary saving owing to insufficient public social safety nets.

46. External deficits imperil the sustainability of growth if they reach a substantial size, irrespective of the underlying causes and in contrast to external surpluses. The sustainability of a current account deficit is a function of the ability of the country to attract foreign capital and of its repayment prospects. Hence, high current account deficits can be sustainable as long as there are willing lenders. However, the larger the stock of net foreign liabilities, the less sustainable is a current account deficit position and even more so a trade deficit considering that a surplus in the trade balance is needed to stabilise the net foreign debt position. Large current account deficits make a country more susceptible to changes in foreign investor sentiment. If foreign investors change their mind about the repayment prospects, a foreign financing gap opens up, which needs to be closed through reduced domestic demand and/or higher exports. Under a flexible exchange rate system, ensuing exchange rate devaluations may imperil financial stability if the domestic debtors hold sizeable amounts of foreign currency denominated liabilities. Under a fixed exchange rate regime, adjustment to reach a sustainable current account balance requires internal devaluations, i.e. price and wage growth below that of trading partners. As witnessed in several euro area peripheral countries, this adjustment may entail prolonged periods of high unemployment.

47. The composition of inflows funding the external gap influences the sustainability of a country's current account deficit and its financial vulnerability. Short-term loans and portfolio inflows are usually more prone to sudden reversal while long-term loans and foreign direct investment (FDI) inflows are regarded as more stable. Moreover, debt contracts require regular payments regardless of the borrowers' economic situation whereas equity and FDI inflows are largely state-contingent liabilities and are generally associated with technology and skill transfers. Recent OECD work finds that the effect of large capital inflows on crises probability is different depending on the type of flows characterising the episode (Furceri et al. 2011). In particular, large debt-driven capital inflows significantly increase the probability of banking, currency and balance of payment crises, whereas if inflows are driven by equity portfolio investment or FDI there is a negligible effect. Other recent OECD work has investigated the role of the financial account structure on the probability of suffering a systematic banking crisis (OECD, 2012c; Ahrend and Goujard, 2012). It shows that the share of debt (especially bank debt) in total external liabilities, short-term bank debt - primarily via bank balance sheet contagion - and currency mismatch between assets and liabilities are positively related to the risk of systemic banking crisis. These findings are in line with the early warning literature, which commonly finds external debt and especially short-term debt to be associated with higher crisis incidence (e.g. Frankel and Saravelos, 2012).

48. Official foreign exchange reserves provide a buffer to stem capital flow reversals as they can be drawn down in the event of a sudden stop. A case in point is the accumulation of foreign reserves by emerging economies following the Asian currency crises of the late 1990s (Didier et al., 2011; Gourinchas and Obstfeld, 2011). Reserve accumulation served two purposes in emerging economies in the aftermath of

10. However, causation is likely to run both ways. For example, Aizenman and Jinjarak (2013) note that current account deficits are useful early warning signals of real estate price valuation changes. 
the crisis (Didier et al., 2011): first, it slowed the appreciation of the domestic currency during the precrisis expansionary period; and second, it served as a self-insurance mechanism during the crisis, deterring currency and banking panics. By eliminating concerns about debt roll-over difficulties, it gave investors less incentives to attack domestic currencies. International reserves also gave central banks room to counteract the depreciation of currencies during the crisis. Official foreign reserves have been frequently found to reduce the incidence of crisis (Frankel and Saravelos, 2012), although possibly with decreasing marginal effectiveness (Ahrend and Goujard, 2012). To assess the appropriateness of official foreign currency reserves, official reserves are typically assessed vis-a-vis GDP, short-term debt, in months of imports and as a ratio of broad money (e.g. M2).

49. Persistent real exchange rate misalignments are among the most robust early warning indicators of financial crises (e.g. Frankel and Saravelos, 2012). Real effective exchange rates are largely driven by the same set of fundamentals and policies as current account balances. Persistent real exchange rate appreciations do not need to signal distortions. For instance, catching-up countries might experience price level convergence with advanced economies related to the Balassa-Samuelson effect. However, absent such convergence effects, persistent real exchange rate appreciations can signal price and cost competitiveness losses. To capture non-price competitiveness, such as product quality, measures of the real effective exchange rates can be supplemented with measures of export market share developments.

Table 5. Indicators of external imbalances

\begin{tabular}{|c|c|c|c|}
\hline Indicator & Description/ & Data source & Available? \\
\hline Current account balance * & In per cent of GDP & OECD & Yes \\
\hline External debt ** & $\begin{array}{l}\text { In per cent of GDP or in per cent of external } \\
\text { liabilities }\end{array}$ & IMF & Yes \\
\hline External bank debt ** & $\begin{array}{l}\text { Debt liabilities towards BIS reporting banks in } \\
\text { per cent of GDP. }\end{array}$ & BIS & Yes \\
\hline External short-term bank debt ** & $\begin{array}{l}\text { Short-term debt liabilities towards BIS } \\
\text { reporting banks with residual maturity up to } \\
\text { and including one year, in per cent of GDP or } \\
\text { in per cent of total debt liabilities towards BIS } \\
\text { reporting banks. }\end{array}$ & BIS & Yes \\
\hline FDI liabilities ** & $\begin{array}{l}\text { Direct investment liabilities, not seasonally } \\
\text { adjusted, percentage of total external } \\
\text { liabilities }\end{array}$ & IMF & Yes \\
\hline Currency mismatch & $\begin{array}{l}\text { Index of the sensitivity of a country's portfolio } \\
\text { to a uniform currency movement by which the } \\
\text { domestic currency moves proportionally } \\
\text { against all foreign currencies. Index between - } \\
1 \text { (zero foreign-currency foreign assets and } \\
\text { only foreign-currency foreign liabilities) and } 1 \\
\text { (only foreign-currency foreign assets and only } \\
\text { domestic-currency foreign liabilities). }\end{array}$ & $\begin{array}{l}\text { Benetrix et } \\
\text { al. (2015) }\end{array}$ & Yes \\
\hline Official foreign exchange reserves ** & $\begin{array}{l}\text { In per cent of GDP, in per cent of external } \\
\text { debt, in per cent of } \mathrm{M} 2 \text {, or in months of } \\
\text { import. }\end{array}$ & $\begin{array}{l}\text { IMF, World } \\
\text { Bank }\end{array}$ & Yes \\
\hline Real effective exchange rate * & CPI or ULC based & OECD & Yes \\
\hline Export performance & $\begin{array}{l}\text { Exports of goods and services relative to } \\
\text { export market for goods and services. }\end{array}$ & OECD & Yes \\
\hline
\end{tabular}

* denotes indicators that are included in the OECD Economic Outlook (Table A1). ** denotes indicators that are included in the OECD Economic Outlook (Table A2).

\section{International spillovers, contagion and global risks}

\subsubsection{The main channels}

50. A key insight from the 2008/09 crisis was that even countries without significant domestic or external imbalances were not insulated from external shocks. OECD economies are highly integrated both 
in terms of trade and financial linkages. Integration confers long-run benefits in terms of economic efficiency, allows risk sharing and leaves a country less vulnerable to domestic shocks. However, integration also makes countries more susceptible to external shocks through spillovers and contagion, in particular in times of global stress. Developments in the rest of the world can spill over to the domestic economy through three main channels: the trade channel, the financial channel and the confidence channel.

51. The trade channel captures changes to the cross-border flow of goods and services that result from shocks in the rest of the world. For instance, a negative demand shock abroad will reduce demand for a country's exports, lowering the price and quantity of goods exported. A negative external supply shock (e.g. oil price shock), tends to increase import prices, squeezing firms' profits and households real disposable income. Spillovers via the trade channel may also depend on a country's degree of trade diversification in terms of products and trading partners. A more diversified trade portfolio will make a country less vulnerable to shocks to particular trading partners and/or trade sectors (e.g. commodities).

52. The rise of global value chains (GVC) has potentially important implications on the trade channel. In particular, indirect trade effects are likely to matter more. For example, the domestic economy might be vulnerable to shocks in a country which is not a direct trading partner, but which operates along the same supply chain. One implication of the rise in GVCs is that it may be more useful to capture vulnerabilities to foreign shocks on domestic GDP by measuring trade exposures in terms of value added than the more traditional measures based on gross exports, which is feasible thanks to the newly developed OECD-WTO trade in value added (TiVA) database. In addition, because of the strong connectivity and specialisation along GVCs, national economies can become more vulnerable to so-called systemic risk, i.e. the risk that a breakdown of one link in the chain can lead to the breakdown of the entire system. During the Great Recession and the 2011 Japanese earthquake, GVCs have acted as important channels of contagion. However, whether a shock in one part of the chain leads to system-wide effects depends on the degree of redundancy in the system, i.e. whether the loss of one supplier can be compensated by other suppliers (OECD, 2013). Empirical evidence on whether GVCs reduce or increase vulnerabilities is scarce so that a final assessment is not yet possible.

53. The financial channel captures cross-border flows of assets and liabilities. Given the importance of banking sector contagion during the global financial crisis and euro area crisis (e.g. Bolton and Jeanne, 2011), it is useful to distinguish between a banking channel, in which spillovers are predominantly transmitted via bank balance sheets, and a non-banking channel. The banking channel can in turn be broken down into an asset and a liability channel. Spillovers through the asset side of banks' balance sheets occur for example if a domestic bank (or a subsidiary of a foreign bank) suffers losses abroad. The resulting decrease in the bank's asset-to-capital ratio may trigger the bank to reduce its balance sheets by reducing lending in the domestic economy (see financial sector imbalances section above). Spillovers through the liability side of the bank balance sheet may occur, if a domestic bank relies on funding from abroad, especially through international inter-banking wholesale markets. Shocks abroad may lead to a reduction in foreign funding. If the domestic bank cannot replace that funding from other sources, it may be forced to cut back domestic lending or sell other assets. Besides these direct financial linkages, indirect contagion may also arise. For example, banks may cut back on loans to a country in response to suffering losses on loans to another country. This "common creditor" contagion has played an important role in the global financial crisis (Ahrend and Goujard, 2012).

54. The non-banking channel operates through international equity and bond markets. A shock abroad may reduce the value of foreign assets held by domestic residents. Through wealth and financial accelerator effects, these losses can translate into reduced domestic demand from consumers and firms. Alternatively, a shock abroad may cause foreign investors to reduce their holdings in the domestic market, leading to a fall in the domestic bond and asset markets, again affecting domestic demand via wealth and financial accelerator effects. 
55. The uncertainty/confidence channel captures changes in the level of uncertainty in the domestic economy caused by shocks in the rest of the world. A negative shock abroad may lead to higher uncertainty of domestic households and firms because of the uncertainty how the foreign shock might ultimately impact the domestic economy. Households may postpone spending when economic prospects become more uncertain because their incentive to 'wait and see' how the economy evolves increases. Firms may reassess their prospects for demand and may postpone investment. Elevated uncertainty may also push up borrowing costs for households and firms as investors demand greater compensation against future risks. ${ }^{11}$ Alternatively, uncertainty and confidence shocks can be transmitted through foreign investors. The emergence of financial stress in one country may serve as a "wake-up call" to re-evaluate the risk of countries in the same region or with similar risk profiles (Goldstein, 1998). Sudden swings in sentiment can occur when investors overestimate economic interdependence between a country in crisis and others, or extrapolate new information on the former to the latter. Such sudden swings in sentiment and the ensuing portfolio rebalancing may lead to sudden reversals of capital flows and thereby contribute to the transmission of financial stress across countries. Some empirical studies suggest that this uncertainty/confidence channel is mainly responsible for the strong comovement across countries during the global financial crisis (e.g. IMF, 2013).

56. The relative importance of the different spillover channels may vary with the underlying shock. For example, financial shocks may be primarily transmitted through financial linkages while demand shocks (e.g. consolidation) may be primarily transmitted through trade channels (IMF, 2013). However, these channels rarely operate in isolation. Instead, they are active simultaneously and interact. For example, shocks transmitted through the uncertainty channel may lead exporters at home to revise their export plans. A shock transmitted through the financial channel might influence trade financing negatively, affecting trade. On the other hand, trade openness can reduce the impact of a sudden stop. In a more open economy, the marginal propensity to import is larger. As a result, a smaller fall in GDP or a smaller currency devaluation is needed to close a given external funding gap (Cavallo and Frankel, 2008).

\subsubsection{Measuring vulnerabilities to international spillovers, contagion and global risks}

57. Vulnerabilities to international spillover and contagion can be measured in a number of ways. For example, indicators of trade openness or financial openness can be used. These measures are likely to capture vulnerabilities to global shocks or shocks originating in major trade or financial centres, such as the United States, the euro area or China (for trade). However, they may be less useful to capture vulnerabilities to spillovers and contagion from more localised shocks as they do not take into account particular exposures of countries.

58. Measures of global imbalances provide another relatively straightforward way of capturing spillover and contagion risk. Global indicators are commonly measured as GDP weighted averages of country specific imbalances, which in principle can be any of the domestic imbalances described in the proceeding sections. The rational for using these indicators is that if imbalances, such as a credit or asset price boom, build up in several countries simultaneously, an unwinding in one country may trigger the unwinding of the imbalance in another country. In addition, if several countries unwind imbalances (e.g. deleverage) at the same time, even countries without imbalances are more likely to be affected through trade and financial channels.

59. The early warning literature has increasingly incorporated such global measures with some success. For example indicators of global liquidity, commonly measured in terms of GDP-weighted credit aggregates, alongside domestic variables have been shown to improve the prediction of crises (e.g. Lo

11. See Bloom (2014) for a review of how uncertainty may affect the real economy. 
Duca and Peltonen, 2013; Babecky et al., 2013; Behn et al., 2013) or of costly asset price booms (Alessi and Detken, 2011). In addition, Babecky et al. (2013) find that heightened global risk aversion (e.g. measured by the VIX index and BAA-rated corporate bond spreads) is typically accompanied by larger economic costs after crises. Behn et al. (2013) find evidence that global equity price growth is positively associated with future banking crises. The main advantage of global and regional indicators - besides their simplicity to construct - is that they may capture risks of contagion through the confidence channel, which is otherwise hard to measure. The main drawback is that the indicators do not vary by country and hence do not allow assessing country specific spillover and contagion risk. Global indicators may also blur the built-up of more geographically confined imbalances. For example, global indicators are likely to have missed the built-up of imbalances in several Asian countries prior to the East Asian crisis. Hence it could be useful to complement global indicators with regional ones.

60. More sophisticated indicators of spillover and contagion risk can be built based on cross-border bilateral data. The main advantage of these indicators is that they capture country-specific spillover or contagion risk. Bilateral trade (e.g. OECD TiVA), portfolio investment (e.g. IMF CPIS data) or bank lending data (e.g. BIS locational banking statistics) can be used to calculate a country's main geographical exposures. These bilateral trade, portfolio investment or bank lending data can then be combined with vulnerability indicators to capture the exposure of the domestic economy to foreign shocks or vulnerabilities. The following equation provides a stylised representation of the indicator construction:

$$
\operatorname{Spill}_{i t}=\sum_{j, j \neq i} w_{i, j, t} V u l n_{j, t}
$$

61. where Spill $_{i t}$ is the indicator of spillover or contagion risk of country $\mathrm{i}$ at time t. $\mathrm{Vuln}_{j, t}$ is a vulnerability indicator of country $j$ at time $t$ to which country $i$ is exposed for example through trade or financial linkages. $w_{i, j, t}$ are weights that add up to one. These weights could be for example the share of exports of country $i$ towards country $j$ in total exports or the share of bank lending of country $i$ towards country $\mathrm{j}$ in total bank lending.

62. Recent OECD work has used indicators of this type to measure spillovers and contagion. Ahrend and Goujard (2012) construct measures of banks' balance sheet contagion by combining bilateral bank lending data with data on country risk ratings. Furthermore, Goujard (2013) investigates cross-country spillovers from fiscal consolidations by combining bilateral trade data with estimates of fiscal shocks. As part of this project it could be envisaged to construct indicators of this type. As measures of vulnerabilities $V u l n_{j, t}$, composite indicators could be constructed based on the indicators from the proceeding sections. ${ }^{12}$

63. Cross-country correlations between consumer and business confidence indicators can provide a rough measure of spillovers trough the confidence/uncertainty channel. For instance, the European Commission (2013) finds a strong correlation between consumer confidence indicators across the euro area

12. Another, relatively new approach based on cross border bilateral data is to construct indicators of the structure of the network of external exposures, which may influence the vulnerability to external shocks. For example, Minoiu et al. (2013) use cross-border bilateral banking data to construct summary indicators of the global banking network, such as the density of the network, i.e. share of observed cross border claims in the total number of possible claims. They show that including these indicators alongside macroeconomic factors can improve probit models of crisis prediction. In particular, they find that higher levels of a country's own connectedness, measured as the number and intensity of a country's financial interlinkages in the network, are associated with higher crisis probability. Lower connectivity among a country's direct financial partners hints at turbulence in the network and potential contagion, and it too is associated with a higher probability of crisis. 
countries with marked differences between the core and periphery countries emerging in the wake of the global financial crisis. In principle, this could just be a result of synchronisation of business cycles, which confidence indicators proxy well, and not a transmission of changes in confidence across countries. However, econometric evidence using Granger-causality tests and VAR analysis have indeed found evidence of spillovers in confidence, especially from the United States to European countries (Dées and Soares Brinca, 2011; Fei, 2011; Dées and Güntner, 2014). Similar econometric analysis using the consumer and business confidence indicators in OECD Main Economic Indicators could be carried out to obtain evidence for all OECD countries. Moreover, for each country a trade-weighted average of foreign confidence indicators can be constructed as in e.g. European Commission (2013).

64. Finally, general equilibrium models can be used to simulate spillover effects. The main advantage of general equilibrium models is that they allow quantifying the magnitude of spillovers for example in terms of domestic GDP losses. The OECD Economics Department uses the global macroeconometric model of the National Institute of Economic and Social Research (NiGEM) to assess spillovers. Most recently, the model has been applied to quantify a simulated growth slowdown in emerging markets on OECD countries (Ollivaud et al., 2014). A drawback of most currently used general equilibrium models is that they mainly capture spillovers through the trade channel. Another drawback is that to keep the models tractable only a limited number of larger economic areas, such as the United States, Japan and the euro area, can be captured.

Table 6. Indicators of spillovers, contagion and global risks

\begin{tabular}{|c|c|c|c|}
\hline Indicator & Description & $\begin{array}{l}\text { Data } \\
\text { Source }\end{array}$ & Available? \\
\hline Trade openness & $\begin{array}{l}\text { Sum of exports and imports in per cent of } \\
\text { GDP }\end{array}$ & OECD & Yes \\
\hline Financial openness & $\begin{array}{l}\text { Sum of total external assets and liabilities } \\
\text { in per cent of GDP. }\end{array}$ & IMF & Yes \\
\hline \multicolumn{4}{|l|}{ Global and regional imbalances } \\
\hline \multicolumn{4}{|l|}{ Liquidity } \\
\hline Total credit & GDP weighted average of individual data & BIS & Yes \\
\hline Bank credit & GDP weighted average of individual data & BIS & Yes \\
\hline \multicolumn{4}{|l|}{ Risk aversion } \\
\hline BAA-rated corporate bond spread & & & No \\
\hline VIX & $\begin{array}{l}\text { Implied volatility of the S\&P } 500 \text { index over the } \\
\text { next } 30 \text { days. Calculated using a range of } \\
\text { options on the S\&P } 500 \text { index. The VIX is quoted } \\
\text { in percentage points and can roughly be } \\
\text { interpreted as the expected movement in the } \\
\text { S\&P } 500 \text { index over the next } 30 \text {-day period. }\end{array}$ & BIS & Yes \\
\hline \multicolumn{4}{|l|}{ Asset prices } \\
\hline Equity prices & GDP weighted average of individual data & OECD & Yes \\
\hline House prices & GDP weighted average of individual data & OECD & Yes \\
\hline
\end{tabular}

\section{Conclusions}

65. The global financial crisis and the high associated economic costs have revived interest in assessing the economic resilience of countries. To this end, this paper discusses the source and nature of potential vulnerabilities that can lead to costly crises in OECD countries. It then proposes a new dataset of more than 70 vulnerability indicators based on the most recent evidence from the early warning literature and lessons learned from the global financial crisis. The indicators are grouped into six areas: i) financial sector imbalances, ii) non-financial sector imbalances, iii) asset market imbalances, iv) public sector 


\section{ECO/WKP(2015)67}

imbalances, v) external sector imbalances and vi) international spillovers, contagion and global risks. The new dataset can help policy makers detect vulnerabilities early on and complement other OECD tools to monitor country-specific risks.

66. Two companion papers complement the analysis provided in this paper. Hermansen and Röhn (2015) show that the majority of the vulnerability indicators proposed in this paper for which there is sufficiently long time series are helpful in predicting severe recessions and crises in the 34 OECD economies and Latvia between 1970 and 2014. Caldera Sánchez et al. (2015) provides a literature overview of work carried out primarily within, but also outside the OECD, on the impact of macroeconomic, financial market and a range of structural policies on vulnerabilities.

\section{BIBLIOGRAPHY}

Acemoglu, D., A. Ozdaglar and A. Tahbaz-Salehi (2015), "Systemic Risk and Stability in Financial Networks", American Economic Review, Vol. 105, pp. 564-608.

Aghion, P., G.-M. Angeletos, A. Banerjee and K. Manova (2010), "Volatility and Growth: Credit Constraints and the Composition of Investment", Journal of Monetary Economics, Vol. 57/3, pp. 246-265, http://dx.doi.org/10.1016/j.jmoneco.2010.02.005

Ahrend, R. and A. Goujard (2012), "International Capital Mobility and Financial Fragility - Part 1. Drivers of Systemic Banking Crises: The Role of Bank-Balance-Sheet Contagion and Financial Account Structure", OECD Economics Department Working Papers, No. 902, OECD Publishing, http://dx.doi.org/10.1787/5kg3k8ksgglw-en

Aizenman, J. and Y. Jinjarak (2013), "Real Estate Valuation, Current Account and Credit Growth Patterns, Before and After the 2008-9 Crisis", NBER Working Paper Series, No. 19190, http://dx.doi.org/10.3386/w19190

Alessi, L. and C. Detken (2011), "Quasi real time early warning indicators for costly asset price boom/bust cycles: A role for global liquidity”, European Journal of Political Economy, Vol. 27/3, pp. 520-533, http://dx.doi.org/10.1016/j.ejpoleco.2011.01.003

André, C. (2010), “A Bird's Eye View of OECD Housing Markets”, OECD Economics Department Working Papers, No. 746, OECD Publishing, http://dx.doi.org/10.1787/5kmlh5qvz1s4-en

Andrews, D., A. Caldera Sánchez and Å. Johansson (2011), "Housing Markets and Structural Policies in OECD Countries", OECD Economics Department Working Papers, No. 836, OECD Publishing, http://dx.doi.org/10.1787/5kgk8t2k9vf3-en

Arregui, N., M. Norat, A. Pancorbo, J. Scarlata (2013), “Addressing Interconnectedness: Concepts and Prudential Tools", IMF Working Paper, WP/13/199, http://www.imf.org/external/pubs/ft/wp/2013/wp13199.pdf 
Babecký, J. et al., (2012), "Banking, Debt and Currency Crises: Early Warning Indicators for developed Countries", ECB Working Paper Series, No. 1485.

http://www.ecb.europa.eu/pub/pdf/scpwps/ecbwp1485.pdf

Babecký, J., T. Havranek, J. Mateju, M. Rusnak, K. Smidkova, B. Vasicek (2013), “Leading Indicators of Crisis Incidence: Evidence from Developed Countries", Journal of International Money and Finance, Vol. 35, pp. 1-19, http://dx.doi.org/10.1016/j.jimonfin.2013.01.001

Baldacci, E., J. McHugh and I. Petrova (2011a), "Measuring Fiscal Vulnerability and Fiscal Stress: A Proposed Set of Indicators", IMF Working Paper, WP/11/94, http://www.imf.org/external/pubs/ft/wp/2011/wp1194.pdf

Baldacci, E. I. Petrova, N. Belhocine, G. Dobrescu and S. Mazraani (2011b), "Assessing Fiscal Stress", IMF Working Paper, WP/11/100, https://www.imf.org/external/pubs/ft/wp/2011/wp11100.pdf

Barnes, S. (2010), "Resolving and Avoiding Unsustainable Imbalances in the Euro Area", OECD Economics Department Working Papers, No. 827, OECD Publishing, http://dx.doi.org/10.1787/5km33sv3jn8s-en

Barrel, R., E. P. Davis, D. Karim and I. Liadze (2010), "Bank Regulation, Property Prices and Early Warning Systems for Banking Crises in OECD countries", Journal of Banking \& Finance, Vol. 34/9, pp. 2255-2264, http://dx.doi.org/10.1016/j.jbankfin.2010.02.015

Behn, M., C. Detken, T. Peltonen and W. Schudel (2013), "Setting Countercyclical Capital Buffers Based On Early Warning Models: Would it Work?", ECB Working Paper Series, No. 1604, http://www.ecb.europa.eu/pub/pdf/scpwps/ecbwp1604.pdf

Bénétrix, A., P. Lane and J. Shambaugh (2015), "International Currency Exposures, Valuation Effects and the Global Financial Crisis," Journal of International Economics, Vol. 96/S1, pp. S98-S109, http://dx.doi.org/10.1016/j.jinteco.2014.11.002.

Bernanke, B. (2009), "Four Questions about the Financial Crisis", Speech at the Morehouse College, Atlanta, Georgia, April 14, 2009, Board of Governors of the Federal Reserve System, http://www.federalreserve.gov/newsevents/speech/bernanke20090414a.htm

Bernanke, B. and M. Gertler (1989), "Agency Costs, Net Worth, and Business Fluctuations", The American Economic Review, Vol. 79, No. 1, pp. 14-31, http://www.jstor.org/stable/1804770

Bertrand, M. and A. Morse (2013), “Trickle-Down Consumption”, NBER Working Paper Series, No. 18883, http://dx.doi.org/10.3386/w18883

BIS (2013), Global Systemically Important Banks: Updated Assessment Methodology and Higher Loss Absorbency Requirement, Bank for International Settlements, http://www.bis.org/publ/bcbs255.pdf

BIS (2012), A Framework for Dealing with Domestic Systemically Important Banks, Bank for International Settlements, http://www.bis.org/publ/bcbs233.pdf

Blanchard, O. and G.M. Milesi-Ferretti (2012), “(Why) Should Current Account Balances Be Reduced?”, IMF Staff Discussion Note, SDN/11/13, http://www.imf.org/external/pubs/ft/sdn/2011/sdn1103.pdf

Blanchard, O. and J. Simon (2001), "The Long and Large Decline in U.S. Output Volatility”, Brookings Papers on Economic Activity, Vol. 2001/1, pp. 135-164, http://www.jstor.org/stable/1209161 
Bloom, N. (2014), "Fluctuations in Uncertainty", Journal of Economic Perspectives, Vol. 28/2, pp. 153176, http://dx.doi.org/10.1257/jep.28.2.153

Blundell-Wignall, A. and C. Roulet (2014), "Macro-prudential policy, bank systemic risk and capital controls", OECD Journal: Financial Market Trends, Vol. 2013/2, http://dx.doi.org/10.1787/fmt2013-5jzb2rhkhks4

Bolton, P. and O. Jeanne (2011), "Sovereign Default Risk and Bank Fragility in Financially Integrated Economies”, IMF Economic Review, Vol. 59, pp. 162-194, http://dx.doi.org/10.1057/imfer.2011.5

Borio, C. and Drehmann, M. (2009), "Assessing the Risk of Banking Crises - Revisited", BIS Quarterly Review, March 2009, pp. 29-46, http://www.bis.org/publ/qtrpdf/r_qt0903e.pdf

Borio, C. and P. Lowe (2002), "Assessing the Risk of Banking Crisis", BIS Quarterly Review, December 2002, pp. 43-52, http://www.bis.org/publ/qtrpdf/r_qt0212e.pdf

Brunnermeier, M. (2009), "Deciphering the Liquidity and Credit Crunch 2007-2008”, Journal of Economic Perspectives, Vol. 23/1, pp. 77-100, http://dx.doi.org/10.1257/jep.23.1.77

Cabral, R. (2013), "A Perspective on the Symptoms and Causes of the Financial Crisis", Journal of Banking \& Finance, Vol. 37/1, pp. 103-117, http://dx.doi.org/10.1016/j.jbankfin.2012.08.005

Caldera Sánchez, A., O. Röhn and M. Rasmussen (2015), "Economic Resilience: What Role for Policies?" OECD Economics Department Working Papers, No. 1251, OECD Publishing.

Catte, P., N. Girouard, R. Price and C. André (2004), "Housing Markets, Wealth and the Business Cycle", OECD Economics Department Working Papers, No. 394, OECD Publishing, http://dx.doi.org/10.1787/534328100627

Cavallo, E. and J. Frankel (2008), "Does openness to trade make countries more vulnerable to sudden stops, or less? Using gravity to establish causality", Journal of International Money and Finance, Vol. 27/8, pp. 1430-1452, http://dx.doi.org/10.1016/j.jimonfin.2007.10.004

Cecchetti, S., A. Flores-Lagunes and S. Krause (2006) "Assessing the Sources of Changes in the Volatility of Real Growth”, NBER Working Paper Series, No. 11946, http://dx.doi.org/10.3386/w11946

Cespedes, L.F. and A. Velasco (2012), "Macroeconomic Performance During Commodity Price Booms and Busts", IMF Economic Review, Vol. 60, pp. 570-599, http://dx.doi.org/10.1057/imfer.2012.22

Chen, R., G. M. Milesi-Ferretti and T. Tressel (2012), "External Imbalances in the Euro Area", IMF Working Paper, WP/12/236, https://www.imf.org/external/pubs/ft/wp/2012/wp12236.pdf

Chinn, M. and H. Ito (2008), "Global Current Account Imbalances: American Fiscal Policy versus East Asian Savings", Review of International Economics, Vol. 16/3, pp. 479-498, http://dx.doi.org/10.1111/j.1467-9396.2008.00741.x

Claessens, S., M. Kose and M. Terrones (2011), “Financial cycles: What? How? When?”, IMF Working Paper, WP/11/76, https://www.imf.org/external/pubs/ft/wp/2011/wp1176.pdf

Corsetti, G. K. Kuester, A. Meier, G. Mueller (2012), "Sovereign Risk, Fiscal Policy, and Macroeconomic Stability”, IMF Working Paper, WP/12/33, http://www.imf.org/external/pubs/ft/wp/2012/wp1233.pdf 
Cottarelli, C. (2011), “The Risk Octagon: A Comprehensive Framework For Assessing Sovereign Risks", http://www.imf.org/external/np/fad/news/2011/docs/Cottarelli1.pdf

Crowe, C. G. Dell'Ariccia, D. Igan and P. Rabanal (2013), "How to Deal with Real Estate Booms: Lessons from Country Experiences", Journal of Financial Stability, Vol. 9/3, pp. 300-319, http://dx.doi.org/10.1016/j.jfs.2013.05.003

Csortos, O. and Z. Szalai (2014), "Early warning indicators: financial and macroeconomic imbalances in Central and Eastern European countries”, MNB Working Papers, Vol. 2014/ 2, Magyar Nemzeti Bank, http://english.mnb.hu/Root/Dokumentumtar/ENMNB/Kiadvanyok/mnben_mnbfuzetek/WP_20142.pdf

Davis, E. P. (2010), “Asset Prices and the Real Economic Activity", ", OECD Economics Department Working Papers, No. 764, OECD Publishing, http://dx.doi.org/10.1787/5kmft7p4dv34-en

Dées, S. and J. Güntner (2014), “The international dimension of confidence shocks”, ECB Working Paper Series, No. 1669, http://www.ecb.europa.eu/pub/pdf/scpwps/ecbwp1669.pdf

Dées, S. and P. Soares Brinca (2011), "Consumer confidence as a predictor of consumption spending: Evidence for the United States and the Euro Area", ECB Working Paper Series, No. 1349, http://www.ecb.europa.eu/pub/pdf/scpwps/ecbwp1349.pdf

Dell'Ariccia, G., D. Igan, L.Laeven, and H. Tong. (2012), "Policies for Macrofinancial Stability: How to Deal with Credit Booms", IMF Staff Discussion Notes, No. 12/6, https://www.imf.org/external/pubs/ft/sdn/2012/sdn1206.pdf

Denizer, C.A., M.F. Iyigun and A. Owen (2002), "Finance and Macroeconomic Volatility", Contributions in Macroeconomics, Vol. 2/1, http://dx.doi.org/10.2202/1534-6005.1048

Didier, T., C. Hevia and S. Schmukler (2011), "How Resilient Were Emerging Economies to the Global Crisis?", Policy Research Working Paper, No. 5637, The World Bank, http://sciie.ucsc.edu/JIMF4/WPS5637_Schmukler.pdf

Duval, R., J. Elmeskov and L. Vogel (2007), "Structural Policies and Economic Resilience to Shocks", OECD Economics Department Working Papers, No. 567, OECD Publishing, http://dx.doi.org/10.1787/140152385131

Dynan, K.E., D.W. Elmendorf and D.E. Sichel (2006), "Can Financial Innovation Help to Reduce Volatility of Economic Activity", Journal of Monetary Economics, Vol. 53/1, http://dx.doi.org/10.1016/j.jmoneco.2005.10.012

Easterly, W., R. Islam and J. Stiglitz (2000), “Explaining growth volatility”, World Bank, Washington D.C., http://documents.worldbank.org/curated/en/2000/01/3387605/explaining-growth-volatility

EBA (2014), Guidelines on Criteria for the Assessment of Other Systemically Important Institutions, European Banking Authority, https://www.eba.europa.eu/regulation-and-policy/ownfunds/guidelines-on-criteria-to-to-assess-other-systemically-important-institutions-o-siis-//regulatory-activity/press-release 


\section{ECO/WKP(2015)67}

Eggertsson, G. and P. Krugman (2012), "Debt, Deleveraging, and the Liquidity Trap: A Fisher-MinskyKoo Approach “, The Quarterly Journal of Economics, Vol. 127/3, pp. 1469-1513, http://dx.doi.org/10.1093/qje/qjs023

European Commission (2013), "Cross-border spillovers in confidence", Quarterly Report on the Euro Area, Vol. 12/3, pp. 26-30,

http://ec.europa.eu/economy_finance/publications/qr_euro_area/2013/pdf/qrea3_section_2_en.pdf

Fei, S. (2011), "The confidence channel for transmission of shocks", Banque de France Working Paper, No. 314, https://www.banque-france.fr/uploads/tx_bdfdocumentstravail/DT314_02.pdf

Frankel, J. and G. Saravelos (2012), "Can leading indicators assess country vulnerability? Evidence from the 2008-09 global financial crisis", Journal of International Economics, Vol. 87/2, pp.216-231, http://dx.doi.org/10.1016/j.jinteco.2011.12.009

FSB (2014), 2014 Update of List of Global Systemically Important Banks, Financial Stability Board, http://www.financialstabilityboard.org/wp-content/uploads/r_141106b.pdf

Furceri, D., S. Guichard and E. Rusticelli (2011), "Episodes of Large Capital Inflows and the Likelihood of Banking and Currency Crises and Sudden Stops", OECD Economics Department Working Papers, No. 865, OECD Publishing.

Girouard, N., M. Kennedy, P. van der Noord and C. André (2006), "Recent House Price Developments: The Role of Fundamentals", OECD Economics Department Working Papers, No. 475, OECD Publishing, http://dx.doi.org/10.1787/864035447847

Goldstein, M. (1998), The Asian Financial Crisis: Causes, Cures, and Systemic Implications, Policy Analyses in International Economics, No. 55, Institute for International Economics.

Goujard, A. (2013), "Cross-Country Spillovers from Fiscal Consolidations”, OECD Economics Department Working Papers, No. 1099, OECD Publishing. http://dx.doi.org/10.1787/5k3txn1mbw8x-en

Gourinchas, P. and M. Obstfeld (2011), "Stories of the Twentieth Century for the Twenty-First", NBER Working Paper Series, No. 17252, http://dx.doi.org/10.3386/w17252

Hanson, S., A. Kashyap and J. Stein (2011), "A Macroprudential Approach to Financial Regulation" Journal of Economic Perspectives, Vol. 25, pp. 3-28, http://www.jstor.org/stable/23049436?seq=1\#page_scan_tab_contents

Hermansen, M. and O. Röhn (2015), "Resilience: The Usefulness of Early Warning Indicators in OECD Countries”,OECD Economics Department Working Papers, No. 1250, OECD Publishing.

Hoeller, P. and D. Rae (2007), "Housing Markets and Adjustment in Monetary Union", OECD Economics Department Working Papers, No. 550, OECD Publishing, http://dx.doi.org/10.1787/208627725571

IMF (2014), "Q\&A: Seven Questions on Financial Interconnectedness", IMF Research Bulletin, Vol. 15/1, pp. 9-14, http://www.elibrary.imf.org/doc/IMF026/21224-9781484346266/212249781484346266/Other_formats/Source_PDF/21224-9781475535198.pdf

IMF (2013), World Economic Outlook, Transitions and Tensions, International Monetary Fund, http://www.imf.org/external/pubs/ft/weo/2013/02/pdf/text.pdf 
IMF (2012), "Dealing with Household Debt" in IMF, World Economic Outlook: Growth Resuming, Dangers Remain, International Monetary Fund, https://www.imf.org/external/pubs/ft/weo/2012/01/pdf/c3.pdf

Jordà O., M. Schularick and A. Taylor (2010), "Financial Crises, Credit Booms, and External Imbalances: 140 Years of Lessons", NBER Working Paper Series, No. 16567, http://dx.doi.org/10.3386/w16567

Jordà O., M. Schularick and A. Taylor (2013), "When Credit Bites Back”, Journal of Money, Credit, and Banking, Vol. 45/2, http://dx.doi.org/10.1111/jmcb.12069

Kaminsky, G. and C. Reinhart (1999), "The Twin Crises: The Causes of Banking and Balance-ofPayments Problems", American Economic Review, Vol. 89/3, pp. 473-500, http://dx.doi.org/10.1257/aer.89.3.473

Kato, R., S. Kobayashi and Y. Saita (2010), "Calibrating the Level of Capital: The Way We See It, Bank of Japan Working Paper Series, No. 10-E-6, https://www.boj.or.jp/en/research/wps_rev/wps_2010/wp10e06.htm/

King, M. (2009), Speech given to the CBI Dinner, Nottingham, at the East Midlands Conference Centre, 20 January 2009, Bank of England, http://www.bankofengland.co.uk/archive/Documents/historicpubs/speeches/2009/speech372.pdf

Kiyotaki, N. and J. Moore (1997), "Credit Cycles", Journal of Political Economy, Vol. 105, No. 2, pp. 211-248, http://dx.doi.org/10.1086/262072

Kopits, G. (2014), "Coping with fiscal risk: Analysis and practice", OECD Journal on Budgeting, Vol. 2014/1, pp. 47-71, http://dx.doi.org/10.1787/16812336

Kumhof, M, R. Ranciere and P. Winant (2013), "Inequality, Leverage and Crises: The Case of Endogenous Default", IMF Working Paper, No. 13/249, http://dx.doi.org/10.5089/9781484310762.001

Laeven L. and F. Valencia (2012), "Systemic Banking Crises Database: An Update", IMF Working Paper, No. 12/163, http://www.palgrave-journals.com/imfer/journal/v61/n2/pdf/imfer201312a.pdf

Lane, P. and G.M. Milesi-Ferretti (2010), “The Cross-Country Incidence of the Global Crisis”, IMF Working Paper, WP/10/171, http://www.imf.org/external/pubs/ft/wp/2010/wp10171.pdf

Lo Duca, M. and T. Peltonen (2013), “Assessing Systemic Risks and Predicting Systemic Events”, Journal of Banking \& Finance, Vol. 37/7, pp. 2183-2195, http://dx.doi.org/0.1016/j.jbankfin.2012.06.010

de la Maisonneuve, C. and J. Oliveira Martins (2013), "A Projection Method for Public Health and LongTerm Care Expenditures", OECD Economics Department Working Papers, No. 1048, OECD Publishing, http://dx.doi.org/10.1787/5k44v53w5w47-en

Mendoza, E. and M. Terrones (2008), "An Anatomy of Credit Booms: Evidence from Macro Aggregates and Micro Data”, NBER Working Paper Series, No. 14049, http://dx.doi.org/10.3386/w14049

Minoiu, C., C. Kang, V.S. Subrahmanian and A. Berea (2013), "Does Financial Connectedness Predict Crises?", IMF Working Paper, WP/13/267, http://www.imf.org/external/pubs/ft/wp/2013/wp13267.pdf 
Myers, S. C. (1977), “Determinants of Corporate Borrowing”, Journal of Financial Economics, Vol. 5/2, pp. 147-175, http://dx.doi.org/10.1016/0304-405X(77)90015-0

OECD (2014a), “OECD@100: Economic Policies for a Shifting World “, ECO/CPE/WP1(2014)2

OECD (2014b), "Vulnerability of Social Institutions", OECD Economics Department Policy Papers, No. 11, http://dx.doi.org/ 10.1787/5jz158r4q0zn-en

OECD (2013), "Global value chains: Managing the risks", in OECD, Interconnected Economies: Benefiting from Global Value Chains, OECD Publishing, http://dx.doi.org/10.1787/9789264189560-10-en

OECD (2012a), OECD Economic Surveys: European Union 2012, OECD Publishing. http://dx.doi.org/10.1787/eco_surveys-eur-2012-en

OECD (2012b), OECD Economic Surveys: Euro Area 2012, OECD Publishing. http://dx.doi.org/10.1787/eco_surveys-euz-2012-en

OECD (2012c), "International Capital Mobility: Which structural Policies Reduce Financial Fragility", OECD Economics Department Policy Papers, No. 2, http://dx.doi.org/10.1787/5k97gkcv5z27-en

OECD (2011), "The Impact of Structural Reforms on Current Account Imbalances", OECD Economics Department Policy Notes, No. 3, http://www.oecd.org/eco/monetary/47236633.pdf

Ollivaud, P., E. Rusticelli and C. Schwellnus (2014), "Would a Growth Slowdown in Emerging Markets Spill Over to High-income Countries?: A Quantitative Assessment", OECD Economics Department Working Papers, No. 1110, OECD Publishing, http://dx.doi.org/10.1787/5jz5m89p82d8-en

Ollivaud, P. and Turner, D. (2015), "The Effect of the Global Financial Crisis on OECD Potential Output", OECD Journal: Economic Studies, Vol. 2014/1.

Price, R. W. and T. Dang (2011), “Adjusting Fiscal Balances for Asset Price Cycles”, OECD Economics Department Working Papers, No. 868, OECD Publishing, http://dx.doi.org/10.1787/5kgc42t3zqklen

Rajan, R. (2010), Fault Lines: How Hidden Fractures Still Threaten the World Economy, Princeton University Press.

Ramskogler, P. (2014), "Origins of the crisis: Drawing the big picture", OECD Publishing, http://www.oecd.org/naec/NAEC_Origins-of-the-Crisis_ENG.pdf

Reinhart, C. and K. Rogoff (2011), "From Financial Crash to Debt Crisis", American Economic Review, Vol. 101/5, pp. 1676-1706, http://dx.doi.org/10.1257/aer.101.5.1676

Reinhart, C. and K. Rogoff (2008), "Banking Crisis: An Equal Opportunity Menace", NBER Working Paper Series, No. 14587, http://dx.doi.org/10.3386/w14587

Rose, A. and M. Spiegel (2011), "Cross-country Causes and Consequences of the Crisis: An Update", Special Issue: Advances in International Macroeconomics: Lessons from the Crisis, European Economic Review, Vol. 55/3, pp. 309-324. http://dx.doi.org/10.1016/j.euroecorev.2010.12.006 
Schich, S. and S. Lindh (2012), "Implicit Guarantees for Bank Debt: Where Do We Stand?", OECD Journal: Financial Market Trends, Vol. 2012/1, http://dx.doi.org/10.1787/fmt-2012-5k91hbvfkm9v

Schularick, M. and A. Taylor (2012), "Credit Booms Gone Bust: Monetary Policy, Leverage Cycles, and Financial Crises, 1870-2008”, American Economic Review, 102, No. 2, pp. 1029-61, http://dx.doi.org/10.1257/aer.102.2.1029

de Serres, A. and A. Drew (2004), “Short-term Economic Resilience”, OECD, ECO/CPE/WP1(2004)10.

Sutherland, D. and P. Hoeller (2012), "Debt and Macroeconomic Stability: An Overview of the Literature and Some Empirics", OECD Economics Department Working Papers, No. 1006, OECD Publishing, http://dx.doi.org/10.1787/5k8xb75txzf5-en

Sutherland, D., P. Hoeller, R. Merola and V. Ziemann (2012), "Debt and Macroeconomic Stability", OECD Economics Department Working Papers, No. 1003, OECD Publishing, http://dx.doi.org/10.1787/5k8xb76rhstl-en

Taylor, A. (2012), "External Imbalances and Financial Crises", NBER Working Paper Series, No. 18606, http://dx.doi.org/10.3386/w18606 


\section{APPENDIX 1: DATA AVAILABILITY OF VULNERABILITY INDICATORS}

Table A1.1: Data availability: indicators of financial market imbalances

\begin{tabular}{|c|c|c|c|c|}
\hline Indicator & Description & Data Source & No. countries & Earliest obs. \\
\hline \multicolumn{5}{|l|}{ Leverage and risk taking } \\
\hline Financial sector gross financial liabilities * & $\begin{array}{l}\text { Defined as liabilities less financial derivatives and } \\
\text { shares and other equity, in per cent of GDP. Based on } \\
\text { consolidated data for most countries. }\end{array}$ & OECD & 32 & 1995 \\
\hline Leverage ratio * & $\begin{array}{l}\text { Defined as regulatory tier } 1 \text { capital to total (unweighted) } \\
\text { assets. }\end{array}$ & IMF & 35 & 2008 \\
\hline Capital ratio & $\begin{array}{l}\text { Defined as regulatory (tier1) capital to risk-weighted } \\
\text { assets }\end{array}$ & IMF & 40 & 2008 \\
\hline Shadow Banking & $\begin{array}{l}\text { Other financial sector assets to GDP or to total financial } \\
\text { sector assets }\end{array}$ & IMF & 25 & 2008 \\
\hline Return on Assets & $\begin{array}{l}\text { Net income before extraordinary items and taxes to total } \\
\text { assets. }\end{array}$ & IMF & 40 & 2007 Q1 \\
\hline Return on Equity & $\begin{array}{l}\text { Net income before extraordinary items and taxes to total } \\
\text { capital and reserves. }\end{array}$ & IMF & 40 & 2007 Q1 \\
\hline Lending standards & $\begin{array}{l}\text { Change in credit standards (tightened or eased) for } \\
\text { enterprises the last three months. }\end{array}$ & ECB & 9 & 2003 Q1 \\
\hline \multicolumn{5}{|l|}{ Too-big-to-fail } \\
\hline \multicolumn{5}{|l|}{ Liquidity and currency mismatches } \\
\hline Liquidity ratio & Liquid assets to total assets or to short term liabilities & IMF & 38 & 2008 \\
\hline Loan-to-deposit ratio & Total (non-interbank) gross loans to customer deposits. & IMF & 32 & 2008 \\
\hline Deposits from abroad & $\begin{array}{l}\text { Total liabilities to non-residents, currency and deposits, } \\
\text { in per cent of total liabilities. }\end{array}$ & IMF & 4 & 2008 \\
\hline Foreign currency mismatch & Net open position in foreign exchange to capital ratio & IMF & 32 & 2008 \\
\hline \multicolumn{5}{|l|}{ Interconnectedness and common exposures } \\
\hline \multicolumn{5}{|l|}{ Interconnectedness } \\
\hline Housing loans & Residential real estate loans to total loans & IMF & 31 & 2008 \\
\hline Commercial real estate loans & Commercial real estate loans to total loans & IMF & 21 & 2010 \\
\hline Domestic sovereign bonds & $\begin{array}{l}\text { Domestic government securities owned (market value), } \\
\text { in per cent of total assets }\end{array}$ & IMF & 7 & 2005 Q4 \\
\hline
\end{tabular}


Table A1.2: Data availability: indicators of private non-financial imbalances

ECO/WKP(2015)67

\begin{tabular}{|c|c|c|c|c|}
\hline Indicator & Description & Data Source & No. countries & Earliest obs. \\
\hline Total private credit & $\begin{array}{l}\text { Lending from all sectors (including foreign) to private } \\
\text { non-financial sector in per cent of GDP. }\end{array}$ & BIS & 33 & 1970 Q4 \\
\hline Private bank credit & $\begin{array}{l}\text { Lending from domestic bank sector to private non- } \\
\text { financial sector in per cent of GDP. }\end{array}$ & BIS & 33 & 1971 Q2 \\
\hline External debt & $\begin{array}{l}\text { Other sector (households, non-financial corporations, } \\
\text { and non-deposit taking financial corporations) external } \\
\text { debt in per cent of GDP. }\end{array}$ & World Bank & 41 & 2002 Q4 \\
\hline \multicolumn{5}{|l|}{ Households } \\
\hline Household credit & $\begin{array}{l}\text { Lending from all sectors (including foreign) to } \\
\text { households in per cent of GDP. }\end{array}$ & BIS & 31 & 1994 Q4 \\
\hline Household gross financial liabilities * & $\begin{array}{l}\text { Defined as liabilities less financial derivatives and } \\
\text { shares and other equity, in per cent of net household } \\
\text { disposable income. Based on consolidated data for } \\
\text { most countries. }\end{array}$ & OECD & 29 & 1995 \\
\hline Debt service costs & $\begin{array}{l}\text { Household debt service and principal to gross } \\
\text { disposable income. }\end{array}$ & IMF & 12 & 2005 \\
\hline Foreign currency denominated liabilities & $\begin{array}{l}\text { Outstanding amounts at the end of the period; in per } \\
\text { cent of GDP. All currencies other than domestic (non- } \\
\text { euro and non-euro area currencies combined). }\end{array}$ & ECB & 22 & 2006Q1 \\
\hline Short-term (<1 year) & $\begin{array}{l}\text { Household short-term loans in per cent of total } \\
\text { household loans. }\end{array}$ & OECD & 25 & 2003 Q4 \\
\hline \multicolumn{5}{|l|}{ Non-financial corporations } \\
\hline Corporate credit & $\begin{array}{l}\text { Lending from all sectors (including foreign) to non- } \\
\text { financial corporations in per cent of GDP. }\end{array}$ & BIS & 31 & 1994 Q4 \\
\hline $\begin{array}{l}\text { Non-financial corporations gross financial } \\
\text { liabilities * }\end{array}$ & $\begin{array}{l}\text { Defined as liabilities less financial derivatives and } \\
\text { shares and other equity, in per cent of GDP. Based on } \\
\text { consolidated data for most countries. }\end{array}$ & OECD & 32 & 1995 \\
\hline Foreign currency denominated liabilities & $\begin{array}{l}\text { Outstanding amounts at the end of the period; in per } \\
\text { cent of GDP. All currencies other than domestic (non- } \\
\text { euro and non-euro area currencies combined). }\end{array}$ & ECB & 22 & 2006Q1 \\
\hline Short-term (<1 year) & $\begin{array}{l}\text { Short-term debt securities and loans in per cent of total } \\
\text { corporate liabilities. }\end{array}$ & OECD & 26 & 1997 \\
\hline
\end{tabular}

1. The earliest year or quarter for which at least 20 countries are observed. In most cases information is available for some countries before the reported year or quarter. If less than 20 countries are available, the earliest date for any country is reported.

* denotes indicators that are included in the OECD Economic Outlook (Table A1). 
Table A1.3: Data availability: indicators of asset market imbalances

\begin{tabular}{|c|c|c|c|c|}
\hline Indicator & Description & Data Source & No. countries & Earliest obs. ${ }^{1}$ \\
\hline \multicolumn{5}{|l|}{ Housing markets } \\
\hline Real house prices * & Deflated by CPI & OECD & 38 & 1986 Q1 \\
\hline Price-to-disposable income ratio & $\begin{array}{l}\text { Nominal house prices to nominal net household } \\
\text { disposable income per capita }\end{array}$ & OECD & 31 & 1995 Q1 \\
\hline Price-to-rent ratio & Nominal house prices to rent prices. & OECD & 33 & 1991 Q1 \\
\hline Residential investment as \% of GDP & $\begin{array}{l}\text { Gross fixed capital formation, housing, in per cent of } \\
\text { GDP. }\end{array}$ & OECD & 35 & 1970 Q1 \\
\hline Employment in construction & As a percentage of total employment & OECD & 33 & 1999 Q1 \\
\hline \multicolumn{5}{|l|}{ Equity markets } \\
\hline Real stock prices & Share price index deflated by CPI & OECD & 42 & 1981 Q1 \\
\hline
\end{tabular}

1. The earliest year or quarter for which at least 20 countries are observed. In most cases information is available for some countries before the reported year or quarter. If less than 20 countries are available, the earliest date for any country is reported.

* denotes indicators that are included in the OECD Economic Outlook (Table A1). 
ECO/WKP(2015)67

Table A1.4: Data availability: indicators of public sector imbalances

\begin{tabular}{|c|c|c|c|c|}
\hline Indicator & Description & Data Source & No. countries & Earliest obs. $^{1}$ \\
\hline \multicolumn{5}{|l|}{ Basic fiscal solvency } \\
\hline Primary budget balance & $\begin{array}{l}\text { Cyclically adjusted (or underlying) government primary } \\
\text { budget deficit in per cent of potential GDP. }\end{array}$ & OECD & 31 & 1991 \\
\hline General government budget balance * & In per cent of GDP & OECD & 39 & 1980 \\
\hline General government debt * & Gross government debt in per cent of GDP & OECD & 32 & 1994 Q2 \\
\hline$(r-g)^{*}$ & $\begin{array}{l}\text { Real } 10 \text {-year sovereign bond yield-potential GDP growth } \\
\text { rate differential. }\end{array}$ & OECD & 36 & 1990 Q2 \\
\hline \multicolumn{5}{|l|}{ Long-term fiscal solvency } \\
\hline Future public spending on pensions & $\begin{array}{l}\text { Projections of future public expenditure on pensions in } \\
\text { per cent of GDP. }\end{array}$ & OECD & 39 & 2010 \\
\hline $\begin{array}{l}\text { Future public spending on health and long- } \\
\text { term care }\end{array}$ & $\begin{array}{l}\text { Projections of future health and long-term care costs in } \\
\text { per cent of GDP. }\end{array}$ & OECD & 40 & 2010 \\
\hline Projected old-age support ratio & $\begin{array}{l}\text { Projections of number of people in working age }(20-64) \\
\text { relative to number of people in retirement age }(65+) \text {. }\end{array}$ & OECD & 42 & 1950 \\
\hline \multicolumn{5}{|l|}{ Government debt composition } \\
\hline Gross financing needs & $\begin{array}{l}\text { Public budget deficit }+ \text { short-term debt by original } \\
\text { maturity + long-term debt with payment due in one year } \\
\text { or less, in per cent of GDP. }\end{array}$ & $\begin{array}{l}\text { OECD, World } \\
\text { Bank }\end{array}$ & 17 & 1995 Q1 \\
\hline Short-term debt & $\begin{array}{l}\text { Short-term gross general government debt in per cent of } \\
\text { gross general government debt. }\end{array}$ & World Bank & 18 & 1995 Q1 \\
\hline \multicolumn{5}{|l|}{$\begin{array}{l}\text { Weighted average maturity of general } \\
\text { government debt }\end{array}$} \\
\hline Debt denominated in foreign currency & In per cent of gross general government debt. & World Bank & 20 & 2011 Q4 \\
\hline Debt held by non-residents & $\begin{array}{l}\text { External gross general government debt in per cent of } \\
\text { gross general government debt. }\end{array}$ & World Bank & 32 & 2003 Q2 \\
\hline Short-term external government debt & In per cent of gross general government debt. & World Bank & 30 & 2003 Q4 \\
\hline \multicolumn{5}{|l|}{ Fiscal risks or uncertainties } \\
\hline Government contingent liabilities & $\begin{array}{l}\text { Government liabilities excluding guarantees to financial } \\
\text { institutions; government guarantees; liabilities related to } \\
\text { private-public partnerships recorded off-balance sheet of } \\
\text { government; liabilities of government controlled entities } \\
\text { classified outside general government; guarantees to } \\
\text { financial institutions }\end{array}$ & Eurostat & 21 & 2013 \\
\hline
\end{tabular}
quarter. If less than 20 countries are available, the earliest date for any country is reported.

* denotes indicators that are included in the OECD Economic Outlook (Table A1). 
ECO/WKP(2015)67

Table A1.5: Data availability: indicators of external imbalances

\begin{tabular}{|c|c|c|c|c|}
\hline Indicator & Description & Data source & No. countries & Earliest obs. \\
\hline Current account balance * & In per cent of GDP & OECD & 42 & 1975 Q1 \\
\hline External debt ** & In per cent of GDP or in per cent of external liabilities & IMF & 41 & 2005 Q1 \\
\hline External bank debt ** & $\begin{array}{l}\text { Debt liabilities towards BIS reporting banks in per cent } \\
\text { of GDP. }\end{array}$ & BIS & 30 & 1996 Q2 \\
\hline External short-term bank debt ** & $\begin{array}{l}\text { Short-term debt liabilities towards BIS reporting banks } \\
\text { with residual maturity up to and including one year, in } \\
\text { per cent of GDP or in per cent of total debt liabilities } \\
\text { towards BIS reporting banks. }\end{array}$ & BIS & 30 & 1994 Q2 \\
\hline FDI liabilities ** & $\begin{array}{l}\text { Direct investment liabilities, not seasonally adjusted, } \\
\text { percentage of total external liabilities }\end{array}$ & IMF & 41 & 2005Q1 \\
\hline Currency mismatch & $\begin{array}{l}\text { Index of the sensitivity of a country's portfolio to a } \\
\text { uniform currency movement by which the domestic } \\
\text { currency moves proportionally against all foreign } \\
\text { currencies. Index between -1 (zero foreign-currency } \\
\text { foreign assets and only foreign-currency foreign } \\
\text { liabilities) and } 1 \text { (only foreign-currency foreign assets } \\
\text { and only domestic-currency foreign liabilities). }\end{array}$ & $\begin{array}{l}\text { Benetrix et al. } \\
\quad(2015)\end{array}$ & 41 & 1990 \\
\hline Official foreign exchange reserves ** & $\begin{array}{l}\text { In per cent of GDP, in per cent of external debt, in per } \\
\text { cent of } \mathrm{M} 2 \text {, in months of import. }\end{array}$ & $\begin{array}{l}\text { IMF, } \\
\text { World Bank }\end{array}$ & 42 & 1970 Q1 \\
\hline Real effective exchange rate * & CPI or ULC based & OECD & 42 & 1970 Q1 \\
\hline Export performance & $\begin{array}{l}\text { Exports of goods and services relative to export market } \\
\text { for goods and services. }\end{array}$ & OECD & 42 & 1975 Q1 \\
\hline
\end{tabular}

1. The earliest year or quarter for which at least 20 countries are observed. In most cases information is available for some countries before the reported year or quarter. If less than 20 countries are available, the earliest date for any country is reported.

* denotes indicators that are included in the OECD Economic Outlook (Table A1). ${ }^{* *}$ denotes indicators that are included in the OECD Economic Outlook (Table A2). 
ECO/WKP(2015)67

Table A1.6: Data availability: indicators of spillovers, contagion and global risk

\begin{tabular}{|c|c|c|c|c|}
\hline Indicator & Description & Data Source & No. countries & Earliest obs. \\
\hline Trade openness & Sum of exports and imports in per cent of GDP & OECD & 42 & 1970 Q1 \\
\hline Financial openness & $\begin{array}{l}\text { Sum of total external assets and liabilities in per cent of } \\
\text { GDP. }\end{array}$ & IMF & 41 & 2005 Q1 \\
\hline \multicolumn{5}{|c|}{ Global and regional imbalances } \\
\hline \multicolumn{5}{|c|}{ Liquidity } \\
\hline Total credit & GDP weighted average of individual data & BIS & & 1970 Q4 \\
\hline Bank credit & GDP weighted average of individual data & BIS & & 1970 Q4 \\
\hline \multicolumn{5}{|c|}{ Risk aversion } \\
\hline \multicolumn{5}{|c|}{ BAA-rated corporate bond spread } \\
\hline VIX & $\begin{array}{l}\text { Implied volatility of the S\&P } 500 \text { index over the next } 30 \\
\text { days. Calculated using a range of options on the S\&P } \\
500 \text { index. The VIX is quoted in percentage points and } \\
\text { can roughly be interpreted as the expected movement in } \\
\text { the S\&P } 500 \text { index over the next } 30 \text {-day period. }\end{array}$ & BIS & & 1986 M1 \\
\hline \multicolumn{5}{|l|}{ Asset prices } \\
\hline Equity prices & GDP weighted average of individual data & OECD & & $1980 \mathrm{M} 1$ \\
\hline House prices & GDP weighted average of individual data & OECD & & 1971 Q1 \\
\hline
\end{tabular}




\section{APPENDIX 2: DETAILS ON DIFFERENCE-IN-DIFFERENCE ESTIMATIONS}

67. Figures 1 to 3 in the main text of this paper display how a given indicator behaved for countries that experienced a crisis compared to countries that did not. To this end, a simple difference-in-difference equation of the following form is estimated:

$$
y_{i t c}=\sum_{k=-40}^{39} \alpha_{k} 1_{t=c+k}+\alpha_{40} 1_{t \geq c+40}+\gamma_{i}+\delta_{t}+\varepsilon_{\text {ite }}
$$

where $y_{i t e}$ is a vulnerability indicator for country $i$ at time $t$, and $\mathrm{c}$ is the starting quarter of a crisis or severe recession episode. The specification controls for country $\left(\gamma_{i}\right)$ and time $\left(\delta_{t}\right)$ fixed effects; $1_{t=c+k}$ is a dummy variable capturing the behaviour of the vulnerability indicator in each quarter ten years before and ten years after a crisis (banking, sovereign debt or currency) or severe recession episodes. ${ }^{13}$ The dummy variable $1_{t \geq c+40}$ includes all available quarters ten years or more after the episode and is interpreted as the long-run correlation between the episode and the vulnerability indicator. The omitted category is the period more than ten years before the episode and also includes countries experiencing no crisis or severe recession. The estimated coefficient $\widehat{\alpha}_{k}$ can be interpreted as the average change of the vulnerability indicator $k$ quarters pre or post an episode relative to the average level of the vulnerability indicator in normal times. The advantage of this difference-in-difference approach compared to simply plotting the average pattern of a given vulnerability indicator a few quarters before, during and after crises and severe recessions is that the country and time dummies capture unobserved country and time specific shocks.

13. Crises data are taken from Babecky et al. (2012). Their dataset covers banking, currency and sovereign debt crises for all 34 OECD countries and Latvia over the period 1970Q1 to 2010Q4. 